\title{
Halk Eğitim Merkezlerinde Çalışan Bireylerin Rekreatif Etkinliklere Katılımlarına Engel Olan Faktörlerin İncelenmesi (Kocaeli İli Örneği)
}

\author{
Examination of Factors that Prevent Participation of Trainers Working in Public \\ Education Centers in Recreational Activities (Kocaeli City Case)
}

\author{
Fatmanur ÖZTÜRK ${ }^{\left(D^{1}\right.}$, Doç. Dr. Betül BAYAZIT ${ }^{\left(D_{2}\right.}$
}

\begin{abstract}
$\ddot{\mathbf{O} z}$
Bu araştırmada, Kocaeli Halk Eğitim Merkezi'nde eğitmen olarak çalışmakta olan bireylerin rekreatif etkinliklere katılımlarına engel olan faktörlerin incelenmesi amaçlanmıştır. Çalışmada betimsel tarama modelinden ilişkisel tarama modeli kullanılmıştır. Araştırmaya, Kocaeli Halk Eğitim Merkezi'nde hem sözleşmeli hem de kadrolu olarak çalışmakta olan 147'si kadın 57'si erkek olmak üzere toplam 204 eğitmen gönüllü olarak katııım sağlamıştır. Alexandris ve Carroll (1997) tarafından geliştirilen, Türkçe uyarlaması, geçerlik ve güvenirlik çalışması Karaküçük ve Gürbüz (2006) tarafından yapılan "Boş Zaman Engelleri" ölçeği kullanılmıştır. Ölçek, toplam 6 alt boyut ve 27 maddeden oluşmaktadır. Araştırmada kullanılan boş zaman engelleri ölçeğinden elde edilen verilerin frekans ve yüzde değerleri alındıktan sonra parametrik testlerden bağımsız örneklem t-testi ve ANOVA testi uygulanmıştır. Anlam düzeyi 0.05 olarak alınmıştır. Elde edilen bulgulara göre, halk eğitim merkezinde çalışan eğitmenlerin rekreatif etkinliklere katılımını etkileyen faktörlerde ölçeğin alt boyutları incelendiğinde ortalamalarının orta düzeye yakın, ancak yüksek olduğu ve boş zaman engellerine maruz kalındığı görülmektedir. Ölçekten elde edilen puan ortalamalarının en yüksek ortalaması tesis yetersizliği boyutunda görülürken en düşük ortalama arkadaş eksikliği boyutunda görülmüştür.
\end{abstract}

Anahtar Kelimeler: Rekreasyon, boş zaman engelleri, halk eğitim merkezi, eğitmen

Makale Türü: Araştırma

\begin{abstract}
In this research is the examine the factors that prevent the participation of trainers working in Kocaeli Public Education Centers in recreational activities. The study group a total of 204 trainers, 147 of whom are women and 57 of whom are men working both contracted and staffed voluntarily participated in this research."Leisure Time Barriers" scale, which was developed by Alexandris and Carroll(1997)and adapted to Turkish and validity and reliability study was performed by Gurbuz and Karakuçuk (2006), was used in this research. The scale consists of 6 sub-dimensions and 27 substances.After the frequency and percentage values of the data obtained from the leisure time barriers used in the research, Independent sample t-test and ANOVA test from parametric tests were applied.The significance level was taken as 0.05.According to the results, when the sub-dimensions of the scale were examined in the factors affecting the participation of trainers working in public education center in recreational activities, it is seen that their averages are close to medium level but they are high, and they are exposed to leisure time barriers. The highest average of the mean scores obtained from the scale was found to be because of the shortage of facilities and the lowest average was found to be the lack of friends.
\end{abstract}

Keywords: Recreation, leisure barriers, public education center, trainer

Paper Type: Research

\footnotetext{
${ }^{1}$ Kocaeli Üniversitesi, Spor Bilimleri Fakültesi, ozturkfatmanur92@gmail.com

${ }^{2}$ Kocaeli Üniversitesi, Spor Bilimleri Fakültesi, bayazitbetul@gmail.com
}

Atıf için (to cite): Öztürk, F. ve Bayazıt, B. (2019). Halk eğitim merkezlerinde çalışan bireylerin rekreatif etkinliklere katılımlarına engel olan faktörlerin incelenmesi: Kocaeli ili örneği. Afyon Kocatepe Üniversitesi Sosyal Bilimler Dergisi, 22(1), 85-105. 


\section{Giriș}

Geçmişten günümüze toplumların yaşam kalitesinin önemli belirleyicilerinden birisi olan zaman kavramı, bazı kişilere göre önemsizce harcanan bazı kişilere göre ise değerli bir yerde bulunup, tasarruf etmenin yollarının arandığ soyut bir kavramdır (Arslan, 2013, s. 1-2). Alın yazın incelendiğinde zaman kavramı ile ilgili birçok tanım karşımıza çıkmaktadır. Bu tanımların geneline baktığımızda zamanla ilgili geçmişten geleceğe doğru olayların birbiri ardına devam ettiği, bireylerin kendi kontrolleri dışında olan, durmadan devam eden bir süreç gibi bazı temel kavramları içerdiği görülmektedir (Tutar, 2007, s. 19-21).

Farklı farklı etkinliklere göre dağılım yaptığımız zaman kavramının, alt başlıklarından biri olan boş zaman kavramı ise kişilerin yaşamında daha özgür olma kaynaklarından biridir. Birçok insan boş zaman aktivitelerine kendi isteğiyle katılır, çünkü aktiviteler kişinin daha özgür hissettiği, ilgi çekici ve kişilerin motive olmasını sağlayan alanlardır (Caldwell, 2005). Özellikle de çalışan kesimler açısından boş zaman, yoğun çalışma temposunun olumsuz etkilerinden sıyrılarak toplumla bütünleşmeye yardımcı olan (Aytaç, 1994) ve değeri gittikçe artan bir yaşam hakk1 olarak düşünülmektedir (Güngörmüş, 2007). Boş zaman aktiviteleri denildiğinde yürüyüş yapma, alışveriş yapma, egzersiz yapma gibi bazı aktiviteler ya da arkadaşlarla sosyalleşme ile geçirilen zaman olarak bilinmektedir (Alghenaim, 2013). Buna ek olarak günlük hayatın uyku, dinlenme ve çalışma dişında kalan, bireyin istediği gibi kullanabileceği zaman olarak da ifade edilebilir (Karaküçük, 1999, s. 94-97).

Bireylerin temel ihtiyaçlarını karşıladıktan sonra kendilerine ayırabildikleri zaman olarak değerlendirilen boş zaman temel olarak üç fonksiyona sahiptir (Sezik Tanyeri, 2008),

1. Dinlenme Fonksiyonu: Boş zamanı en fazla karakterize eden dinlenme, yeniden elde etme ya da çalışma sonrası oluşan stres ve yorgunluğun uzaklaştırılması ile bedensel yıpranmaları ve sinir gerilimlerini ortadan kaldırmaya yardımcı olan bir rol üstlenmiştir (Karaküçük, 2005).

2. Gelişim Fonksiyonu: İnsan düşüncelerini, günlük yaşamdaki eylemlerin sıradanlığından kurtaran, daha geniş sosyal katılımı sağlayan, bireyin kişiliğini geliştirmesine ve göstermesine firsat veren aynı zamanda da çıkarcı olmayan etkinlikleri içermektedir (Karaküçük, 2005.)

3. Ĕ̆lenme Fonksiyonu: Kişilerin boş zamanını değerlendirip aynı zamanda rahatlamaları açısından eğlenme fonksiyonu önemli bir yere sahiptir (Ayhan, 2017). Spora ve eğlenceye olan ilgi her geçen gün giderek artmakta ve buna paralel olarak kişilerin sağlıklarına, duygusal, fiziksel ve psikolojik ruh hallerine verdikleri önemde artmaktadır (Horner ve Swarbrooke, 2005).

Günümüzde hem iş hayatının sorumlulukları hem de diğer zorunlu etkinliklerin yoğun geçmesi sebebiyle ortaya çıkan yorgunluk hissiyatı sonucu, kişilerin boş zamanlarında rekreasyonel etkinliklere yönelerek yaşamları da vazgeçilmez duruma gelmiş, dinlenme ve rahatlama aracı olarak yeniden toparlanma sağlayacak bir yardımcı halini almıştır (Tel ve Kökaslan, 2008).

Rekreasyon; sadece boş zamanda yapılan, kişiye göre bir amacı bulunan, kişisel olarak tatmin ve isteğe bağlı şekilde gönüllülük esasına dayalı, farklı birine devredilemeyen, kişiyi canlandıran ve mutluluk veren, aktif ve pasif olarak yapılabilen, her türlü fiziksel, zihinsel, ruhsal ve sosyal tüm etkinlikler olarak tanımlanabilir (Güngörmüş, 2007). Kişiler bu tür aktiviteler sonucunda hayatın monotonluğundan kurtularak farklı deneyimler kazanırlar. (Tütüncü ve Aydın, 2014). Rekreasyon, boş zamana göre daha dar bir ifadedir ve eğlence anlayışını yansıtmaktadır. Tüm bu kavramlara bakıldığında önemli olan, boş zaman kavramının diğerlerinden daha geniş bir olayı ifade etmesidir. Boş zaman esnasında eğlenceli tecrübelere sahip olma boş zamana katılım gösterenlerin asıl amacıdır (Dalay, 2018). Günümüzde rekreasyon ve spor hemen hemen aynı 
çağrışımlarda bulunan terimlerdir. Rekreasyonel spor aktiviteleri her geçen gün daha popüler bir hal almaktadır (Sekot, 2013).

Rekreasyonun en geniş alanlarından olan spor, ilgi çekici ve farklı seçenekleri olan etkinliklerdir. Spordaki aktivite çeşitliliği, macera, hırs, azim, kendini keşfetme duygularının ortaya çıkmasının yanı sıra sağlık açısından da olumlu katkıları olduğu bilinmektedir (Has, 2016). Sporun sağlık yönünden önemli nitelikleri sahip olması, her kesime uygun olması, kolay ulaşılabilir olması sportif rekreasyonun baskın yönleri arasındadır. Sanayileşmeyle birlikte ortaya çıkan toplumsal kalabalık, trafik sorunu, ses kirliliği ve stres bireylerin boş zamanlarında rahatlayıp canlanmaları için sportif rekreasyonel aktivitelere katılmaya yönlendirmiştir (Şahin ve Kocabulut, 2014).

Rekreatif etkinliklerin günlük hayatta bireyler üzerinde mutlu hissetme, memnuniyet duyma, hoşnut olma gibi faydalar sağladığı bilinmektedir. Rekreatif etkinliklere katılımın sağladığı bu olumlu tutuma rağmen, kişilerin çeşitli engellere maruz kalarak kendileri için oldukça önemli olan bu tür aktivitelere katılım gösteremedikleri görülmektedir. Rekreatif engel kavramı, bireylerin boş zamanlarında rekreatif aktivitelere katılımları esnasında karşı karşıya kaldıkları engel ya da sınırlandırmalar olarak tanımlanmaktadır (Karaküçük ve Gürbüz, 2007).

Crawford ve Godbey (1987)'in geliştirdikleri ve engelleri sınıflandırdıkları modele göre; bireyin boş zaman aktivitelerine katılımı üç ana faktör tarafından engellenir.

Bu faktörler şu şekildedir (Crawford ve Godbey, 1987, s. 119-127);

1. Bireysel faktörler: Bireysel faktörlerde bahsedilen bireylerin psikolojik durumları ve tutumlarıdır. Kişinin kendi yeteneklerinin farkında olması seviyesini bilmesi, aktiviteye karşı tutumu ve aktiviteye uygun olup olmadığını algılaması sonucu aktiviteye verilebilecek etkidir.

2. Bireylerarası faktörler: Bireyler arasındaki etkileşimin yada bireyler arasındaki iletişimin neticesidir. Aktiviteye katılım için bir arkadaş bulmak, para ve vakit gibi faktörlerdir.

3. Yapısal faktörler: Önemli faktörlerden biri olan yapısal faktörler ulaşım, tesislerin kalitesi ve erişilebilirliği bireyin karşılaşabileceği yapısal engeller karşımıza çıkmaktadır.

Boş zamanlarda sportif rekreasyonel aktivitelere katılmak için ayrılan zamana engel olan diğer faktörler genellikle kişinin kendi kontrolü dışında oluşan tesis ve malzeme yetersizliği, kişinin çalıştığ 1 kurumdaki mesai saatlerinin fazla olması, öğrenciler için ders saat yükünün fazla olması, ders saatleriyle kullanılacak rekreatif tesislerin kullanım saatlerinin uyumsuzluğu, cinsiyet, yaş, gelir düzeyi, eğitim seviyesi, bilinçsiz spor eğitimi verilmesi ve bunun sonucunda belli alışkanlıkların oturmaması, katılım ücretlerinin yüksek olması gibi faktörler sayılabilmektedir (Ergül, 2008). Genel itibariyle tüm engeller düşünüldüğünde en büyük engelin zaman eksikliği olabileceği üzerinde durulabilir (Ayhan, 2017).

Alan yazın tarandığında rekreatif etkinliklere katılımın önündeki engellere yönelik araştırmaların genellikle üniversite (Ekinci ve diğerleri, 2014; Emir, 2012; Polat, 2017; Şahin ve Kocabulut, 2014) öğrencileri ile gerçekleştirildiği belirlenmiştir. Ayrıca çalışan bireylerle yapılan çalışmalar da mevcuttur (Dalay, 2018; Has, 2016; Öztürk, 2013; Sabancı, 2016). Has (2016) yapmış olduğu çalışmada sağlık sektöründe çalışanların boş zamanlarında rekreasyon etkinliklerine katılımlarının önündeki engelleri belirlemeye çalışmış; Öztürk (2013), sanayi çalışanlarının rekreatif aktivitelere katılımlarının örgütsel bağl1lık ve tükenmişlik düzeylerine etkisini araştırmıştır. Dalay (2018) ve Sabancı (2016) ise öğretim elemanları ile benzer amaç doğrultusunda çalışmalarını yürütmüşlerdir.

Tüm bu bilgiler doğrultusunda mevcut araştırma, yapılan çalışmalardan farklı olarak halk eğitim merkezinde farklı branşlarda eğitmen olarak görev yapan bireylerle yürütülmüştür. Son 
dönemlerde artış gösteren ve bir hayli önem kazanan halk eğitim merkezlerindeki iş imkânları doğrultusunda çalışan eğitmenlerin iş hayatı dışındaki alanda sportif açıdan bazı değişkenler bakımından nasıl engellerle karşılaşıldığının belirlenmesinin yapılacak yeni çalışmalar için kaynak olacağı ve literatüre katkı sağlayacağı düşünülmektedir.

\section{Yöntem}

Halk Eğitim Merkezinde eğitmen ve usta öğretici olarak çalışmakta olan bireylerin rekreatif etkinliklere katılımlarına engel olan faktörlerin incelenmesi amacıyla yapılan bu çalışmada betimsel tarama modeli kullanılmıştır. Tarama modelleri geçmişte ya da varlığını sürdüren bir durumu olduğu şekli ile betimlemeyi ve açıklamayı amaç edinen araştırmalar için uygun bir modeldir (Karasar, 2011, s. 77).

\subsection{Katılımcılar}

Araştırmanın çalışma grubu amaçlı örnekleme yöntemine göre belirlenmiştir. Merkezde sözleşmeli 442, kadrolu 24 olmak üzere toplam 466 eğitmen görev yapmaktadır. 2018-2019 yılında Kocaeli Halk Eğitim Merkezi'ne bağlı olarak merkez ve ilçede hem sözleşmeli hem de kadrolu olarak çalışmakta olan 147'si kadın 57'si erkek olmak üzere toplam 204 eğitmen ve usta öğretici gönüllü olarak katılmıştır. Çalışma grubuna ait demografik özellikler sırası ile sunulmuştur.

Tablo 1. Katılımcıların branşına yönelik frekans ve yüzde değerlerine ilişkin dağılımı

\begin{tabular}{lcc}
\hline Branş & N & \% \\
\hline Spor & 59 & 28,9 \\
Müzik & 17 & 8,3 \\
Sahne & 10 & 4,9 \\
Mesleki Gelişim & 8 & 3,9 \\
Dikiş & 30 & 14,7 \\
Öğretmen & 36 & 17,6 \\
El Sanatları & 34 & 16,7 \\
Programlama & 10 & 4,9 \\
Toplam & 204 & 100,0 \\
\hline
\end{tabular}

Tablo 1'de, araştırmaya katılan katılımcıların çoğunun mesleğinin spor ile ilgili olduğu $(\% 28,9)$, yarıya yakının öğretmen $(\% 17,6)$ ve el sanatları $(\% 16,7)$ mesleklerine sahip oldukları belirtilmiştir.

Tablo 2. Katılımcıların cinsiyet ile ilgili frekans ve yüzde değerlerine ilişkin dağılımı

\begin{tabular}{ccc}
\hline Cinsiyet & N & \% \\
\hline Kadın & 147 & 72,1 \\
Erkek & 57 & 27,9 \\
Toplam & 204 & 100,0 \\
\hline
\end{tabular}

Tablo 2' de, araştırmaya katılan katılımcıların 147'sinin (\%72,1) kadın, 57'sinin (\%27,9) erkek olduğu görülmektedir. 
Tablo 3. Katılımcıların yaş ile ilgili frekans ve yüzde değerlerine ilişkin dağılımı

\begin{tabular}{lcc}
\hline Yaş & N & \% \\
\hline $20-27$ & 41 & 20,1 \\
$28-35$ & 50 & 24,5 \\
$36-43$ & 57 & 27,9 \\
$44-51$ & 31 & 15,2 \\
$52-59$ & 20 & 9,8 \\
60 yaş ve & 5 & 2,5 \\
üzeri & 204 & 100,0 \\
Toplam & 204 \\
\hline
\end{tabular}

Tablo 3' te, araştırmaya katılan katılımcıların 20-27 yaş aralığını41 kişi (\%20,1) , 28-35 yaş aralığını 50 kişi $(\% 24,5), 36-43$ yaş aralığını 57 kişi (\%27,9), 44-51 yaş aralığını 31 kişi $(\% 15,2)$, 52-59 yaş aralığını 20 kişi $(\% 9,8)$ ve 60 yaş ve üzeri yaş aralığını 5 kişi $(\% 2,5)$ oluşturmaktadır.

Tablo 4. Katılımcıların Medeni Durum ile İlgili Frekans ve Yüzde Değerlerine İlişkin Dağılımı

\begin{tabular}{lcc}
\hline Medeni Durum & $\mathbf{N}$ & $\mathbf{\%}$ \\
\hline Evli & 119 & 58,3 \\
Bekar & 68 & 33,3 \\
Boşanmış & 9 & 4,4 \\
Diğer & 8 & 3,9 \\
Toplam & 204 & 100,0 \\
\hline
\end{tabular}

Tablo 4' te, araştırmaya katılan katılımcıların 119 kişi $(\% 58,3)$ evli bireyler, daha sonra 68 kişi $(\% 33,3)$ bekar bireyler, sonrasında 9 kişi $(\% 4,4)$ boşanmış bireyler ve en azını da 8 kişi olarak $(\% 3,9)$ diğer grubuna ait bireyler oluşturmaktadır.

Tablo 5. Katılımcıların çocuk sayısı ile ilgili frekans ve yüzde değerlerine ilişkin dağılımı

\begin{tabular}{lcc}
\hline Çocuk Sayısı & $\mathbf{N}$ & $\mathbf{\%}$ \\
\hline Çocuk yok & 90 & 44,1 \\
1 çocuk & 38 & 18,6 \\
2 çocuk & 68 & 33,3 \\
3 çocuk & 8 & 44,1 \\
4 çocuk ve üzeri & 0 & 0 \\
Toplam & 204 & 100,0 \\
\hline
\end{tabular}

Tablo 5'te, araştırmaya katılan katılımcılardan çocuk sahibi olmayan 90 kişi $(\% 44,1), 2$ çocuk sahibi olan 68 kişi $(\% 33,3), 1$ çocuk sahibi olan 38 kişi olduğu $(\% 18,6), 4$ çocuk ve üzerinde çocuğa sahip olan hiç bir katılımcının olmadığı görülmüştür.

Tablo 6. Katılımcıların toplam geliri ile ilgili frekans ve yüzde değerlerine ilişkin dağılımı

\begin{tabular}{lcc}
\hline Toplam Gelir & $\mathrm{N}$ & $\%$ \\
\hline 2000TL ve alt1 & 117 & 57,4 \\
2001TL-3000TL & 47 & 23,0 \\
3001TL-4000TL & 16 & 7,8 \\
4001TL-5000TL & 14 & 6,9 \\
5001TL ve üzeri & 10 & 4,9 \\
Toplam & 204 & 100,0 \\
\hline
\end{tabular}

Tablo 6'da, araştırmaya katılan katılımcılardan 117 kişi $(\% 57,4) 2000 \mathrm{TL}$ ve altında gelire sahip oldukları, 47 kişi (\%23,0) 2001-3000 TL arasında gelire sahip oldukları, 16 kişi $(\% 7,8)$ 3001-4000 TL arasında gelire sahip oldukları, 14 kişi $(\% 6,9)$ 4001- 5000 TL arasında gelire sahip oldukları, 10 kişinin $(\% 4,9) 5001 \mathrm{TL}$ ve üzeri gelire sahip oldukları tespit edilmiştir. 
Tablo 7. Katılımcıların eğitim düzeyi ile ilgili frekans ve yüzde değerlerine ilişkin dağılımı

\begin{tabular}{lcc}
\hline Eğitim Düzeyi & N & \% \\
\hline Lise Mezunu & 70 & 34,3 \\
Lisans & 93 & 45,6 \\
Lisans Üstü & 11 & 5,4 \\
Diğer & 30 & 14,7 \\
Toplam & $\mathbf{2 0 4}$ & $\mathbf{1 0 0 , 0}$ \\
\hline
\end{tabular}

Tablo 7'de araştırmaya katılan katılımcıların neredeyse yarısı olan 93 kişi $(\% 45,6)$ lisans mezunu, 70 kişi $(\% 34,3)$ lise mezunu, 30 kişi $(\% 14,7)$ diğer grubunda, 11 kişi ise $(\% 5,4)$ lisansüstü eğitim almış kişiler olarak bulunmuştur.

Tablo 8. Katılımcıların Çalışma Yılı ile İlgili Frekans ve Yüzde Değerlerine İlişkin Dağılımı

\begin{tabular}{lcc}
\hline Çalışma Yılı & N & \% \\
\hline 1-3 y1l & 72 & 35,3 \\
4-6 y1l & 44 & 21,6 \\
7-9 y1l & 20 & 9,8 \\
10 y1l ve üzeri & 68 & 33,3 \\
Toplam & $\mathbf{2 0 4}$ & $\mathbf{1 0 0 , 0}$ \\
\hline
\end{tabular}

Tablo 8'de, araştırmaya katılan katılımcıların çalışma yıllarında 1-3 yıl arasında 72 kişi (\%35,3), 10 yıl ve üzeri çalışan 68 kişi $(\% 33,3)$, 4-6 yıl arasında çalışan 44 kişi $(\% 21,6)$ ve 7-9 yıl arasında çalışan 20 kişi $(\% 9,8)$ şeklinde olduğu görülmüştür.

Tablo 9. Katılımcıların boş olduğu saatler ile ilgili frekans ve yüzde değerlerine ilişkin dağılımı

\begin{tabular}{lcc}
\hline Boş Saat & N & \% \\
\hline 1-3 saat & 130 & 63,7 \\
4-6 saat & 58 & 28,4 \\
7-9 saat & 11 & 5,4 \\
10 saat ve üzeri & 5 & 2,5 \\
Toplam & 204 & 100,0 \\
\hline
\end{tabular}

Tablo 9' da araştırmaya katılan katılımcılardan 130 kişi $(\% 63,7)$ gün içerisinde 1-3 saat aralığında boş zamanı olduğu, 58 kişi $(\% 28,4)$ gün içerisinde 4-6 saat aralığında boş zamanı olduğu, 11 kişi $(\% 5,4)$ gün içerisinde 7-9 saat aralığında boş zamanı olduğu, 5 kişi $(\% 2,5) 10$ saat ve üzerinde boş zamanın olduğu görülmüştür.

\subsection{Veri Toplama Araçları}

Araştırma sürecinde kullanılan veri toplama araçları sırası ile sunulmuştur.

\subsubsection{Kişisel Bilgi Forumu}

Bu bölümde araştırmaya katılan katılımcıların branş, cinsiyet, yaş, medeni durum, çocuk sayısı, toplam geliri, eğitim düzeyi, çalışma yıl1, boş saatleri ile ilgili bilgilere yer verilmiştir.

\subsubsection{Boş Zaman Engelleri Ölçeği}

Araştırmada veri kaynağı olarak Alexandris ve Carrol (1997) tarafından geliştirilen, "Boş Zaman Engelleri” ölçeği kullanılmıştır. 29 madde 7 alt boyuttan oluşan ölçeğin Türk Toplumu için geçerlik ve güvenirlik çalışması ise Karaküçük ve Gürbüz (2006) tarafindan yapılmıştır. Orijinal ölçekte yer alan 2 maddenin $(10,11)$ faktör yükleri 0,40 ' in altında olduğu için ölçeğin Türkçe versiyonundan çıkarılmıştır. Faktör analizi sonuçları ölçeğin Türkçe versiyonu için bireyleri Boş Zaman Engellerini belirlemeye iten, (1) "zaman ve ilgi eksikliği", (2) "birey psikolojisi”, (3) "bilgi eksikliği”, (4) "ulaşım sorunu”, (5) "tesis yetersizliği” ve (6) "arkadaş 
eksikliği" gibi 6 alt boyuttu ölçmeye yönelik 27 maddeden oluşmaktadır. Bireylerin Boş Zaman Engelleri, "Kesinlikle Önemsiz (1)" ve "Önemsiz (2)", "Önemli (3)", ve "Çok Önemli (4)" şeklinde 4'lü likert tipi ölçek üzerinde değerlendirilmektedir. Zaman ve ilgi eksikliğì" 21, 22, 23, 24, 25, 26 ve 27. maddelerden, "birey psikolojisi" 1, 2, 3, 4, 5 ve 6 . maddelerden, "bilgi eksikliği" 7, 8 ve 9. maddelerden, "ulaşım sorunu" $14,15,16$ ve 17 . maddelerden, "tesis yetersizliği" 10 , 11,12 ve 13. maddelerden ve "arkadaş eksikliği" ise 18,19 ve 20 . maddelerden oluşmuştur. Ölçeğin güvenirliğini test etmek için hesaplanan Cronbach Alpha iç tutarlılık katsayıları alt boyutlarda 0,67 (zaman) ile 0,82 (bilgi eksikliği) arasında bulunmuştur. Toplam ölçek iç tutarlılık katsayısı ise 0,84 olarak hesaplanmıştır. Yapılan bu çalışmada ise toplam ölçek Cronbach Alpha iç tutarlılık katsayıları 27 madde 6 alt boyut için 0,90 olarak bulunmuştur.

\subsection{Veri Toplama Süreci}

Çalışma için Kocaeli Milli Eğitim İl Müdürlüğü'nden ve Kocaeli Halk Eğitim Merkezi'nden gerekli izinler alındıktan sonra, kurs merkezleri tek tek gezilmiş olup araştırma ve ölçekler ile ilgili gerekli açıklamalar katılımcılara yapılmıştır. Eş zamanlı olarak Google formlar da oluşturulan online veri toplama aracı, Halk Eğitim Merkezi'nden tüm eğitmenlere mesaj yolu ile gönderilmiş ve ulaş1labilirlik arttırılmaya çalışılmıştır. Bir formun doldurulması yaklaşı 15 dakika sürmüştür. Uygulamalar eğitmenlerin anket formuna gönüllü katılımı sonucu tamamlanmıştır. Tamamlanan ölçekler incelenmiş ve eğitmenler tarafindan tam olarak doldurulmayan ölçekler çalışma kapsamı dışında bırakılmıştır.

\subsection{Verilerin Analizi}

Elde edilen veriler, SPSS 21.0 paket programı ile analiz edilmiştir. Araştırmada kullanılan boş zaman engelleri ölçeğinden elde edilen verilerin frekans ve yüzde değerleri alındıktan sonra parametrik testlerden olan bağımsız örneklem t testi (Independent sample t-test) ve ANOVA testi uygulanmıştır. Katılımcıların boş zaman engelleri ölçeğinden aldıkları puanın cinsiyet değişkenine göre farklılaşma durumu bağımsız t testi; mesleki branş, yaş, medeni durum, çocuk sayısı, aylık ortalama gelir, eğitim düzeyi, meslekte çalışma yılı, günlük ortalama boş denebilecek saat aralığı farklılaşma durumları ise OneWay ANOVA, varyans analizi sonucu homojenlik durumuna göre Post Hoc testlerinden Tukey testi ile analiz edilmiştir. Anlam düzeyi 0.05 olarak alınmıştır.

\section{Bulgular}

\subsection{Katılımcıların Boş Zaman Engellerinin Alt Boyutlarına İlişkin Bulgular}

Boş zaman engellerinin her bir boyutuna ilişkin eğitmenlerin ölçme aracından aldıkları puanlarla ilgili olarak; aritmetik ortalama $(\overline{\mathrm{X}})$, minimum-maksimum puanları ve standart sapma (SS) değerleri Tablo 10'da gösterilmiştir.

Tablo 10. Boş zaman engelleri boyutlarının ortalama, minimum- maksimum puanları ve standart sapma değerleri

\begin{tabular}{lccccc}
\hline Özellikler & N & Min & Max & $\overline{\mathbf{X}}$ & SS \\
\hline Zaman ve ilgi eksikliği & 204 & 1,86 & 4,00 & 2,89 &, 439 \\
Birey psikolojisi & 204 & 1,00 & 4,00 & 2,81 &, 634 \\
Bilgi eksikliği & 204 & 1,00 & 4,00 & 3,04 &, 734 \\
Ulaşım sorunu & 204 & 1,75 & 4,00 & 3,09 &, 591 \\
Tesis yetersizliği & 204 & 1,50 & 4,00 & 3,17 &, 519 \\
Arkadaş eksikliği & 204 & 1,00 & 4,00 & 2,52 &, 649 \\
\hline
\end{tabular}

Tablo 10'da görüldüğü üzere, eğitmenlerin ölçme aracına verdikleri cevaplara bakıldığında en fazla ortalamanın $(\overline{\mathrm{X}}=3,17)$ tesis yetersizliği, en az ortalamanın ise $(\overline{\mathrm{X}}=2,52)$ arkadaş eksikliği boyutunda olduğu belirlenmiştir. Genel ortalamalara bakıldığında ise zaman ve ilgi eksikliği, 
birey psikolojisi, bilgi eksikliği, ulaşım sorunu, tesis yetersizliği ve arkadaş eksikliği boyutlarında boş zaman engellerinin orta düzeyin üzerinde olduğu söylenebilir.

\subsection{Katılımcıların Boş Zaman Engellerinin Mesleki Branş Değiş̧keni Açısından Farklılaşma Durumu Alt Boyutlarına İlişkin Bulgular}

Eğitmenlerin boş zaman engellerinin mesleki branş değişkenine göre farklılaşma durumuna ilişkin yapılan tek yönlü OneWay ANOVA sonuçları değerleri Tablo 11'de sunulmuştur.

Tablo 11. Halk eğitim merkezlerinde çalışan eğitmenlerin boş zaman engellerinin mesleki branş değişkenine ilişkin OneWay ANOVA sonuçları

\begin{tabular}{|c|c|c|c|c|c|c|c|}
\hline Boyutlar & Gruplar & Branş & $\mathbf{N}$ & $\overline{\mathbf{X}}$ & SS & $\mathbf{F}$ & p \\
\hline \multirow{9}{*}{$\begin{array}{l}\text { Zaman ve ilgi } \\
\text { eksikliği }\end{array}$} & 1 & Spor & 59 & 2,95 & 487 & \multirow{9}{*}{1,248} & \multirow{9}{*}{,279 } \\
\hline & 2 & Müzik & 17 & 2,92 & 361 & & \\
\hline & 3 & Sahne & 10 & 2,72 &, 326 & & \\
\hline & 4 & $\begin{array}{l}\text { Mesleki } \\
\text { Gelişim }\end{array}$ & 8 & 3,00 & ,534 & & \\
\hline & 5 & Dikiş & 30 & 2,98 & ,444 & & \\
\hline & 6 & Öğretmen & 36 & 2,83 & ,392 & & \\
\hline & 7 & El sanatları & 34 & 2,87 &, 426 & & \\
\hline & 8 & Programlama & 10 & 2,62 &, 432 & & \\
\hline & 9 & Toplam & 204 & 2,89 & ,439 & & \\
\hline \multirow{9}{*}{$\begin{array}{l}\text { Birey } \\
\text { psikolojisi }\end{array}$} & 1 & Spor & 59 & 2,74 & , 754 & \multirow{9}{*}{1,273} & \multirow{9}{*}{,265 } \\
\hline & 2 & Müzik & 17 & 2,67 & ,610 & & \\
\hline & 3 & Sahne & 10 & 2,73 &, 850 & & \\
\hline & 4 & $\begin{array}{l}\text { Mesleki } \\
\text { Gelişim }\end{array}$ & 8 & 2,97 & , 449 & & \\
\hline & 5 & Dikiş & 30 & 2,98 &, 465 & & \\
\hline & 6 & Öğretmen & 36 & 2,79 &, 534 & & \\
\hline & 7 & El sanatları & 34 & 2,96 &, 595 & & \\
\hline & 8 & Programlama & 10 & 2,50 & ,593 & & \\
\hline & 9 & Toplam & 204 & 2,81 & ,634 & & \\
\hline \multirow{9}{*}{ Bilgi eksikliğgi } & 1 & Spor & 59 & 3,02 & ,797 & \multirow{9}{*}{1,121} & \multirow{9}{*}{, 351} \\
\hline & 2 & Müzik & 17 & 2,94 & ,648 & & \\
\hline & 3 & Sahne & 10 & 2,96 &, 881 & & \\
\hline & 4 & $\begin{array}{l}\text { Mesleki } \\
\text { Gelişim }\end{array}$ & 8 & 2,95 & ,966 & & \\
\hline & 5 & Dikiş & 30 & 3,18 & ,676 & & \\
\hline & 6 & Öğretmen & 36 & 2,97 & 709 & & \\
\hline & 7 & El sanatları & 34 & 3,26 & ,623 & & \\
\hline & 8 & Programlama & 10 & 2,66 & ,702 & & \\
\hline & 9 & Toplam & 204 & 3,04 & ,734 & & \\
\hline \multirow{9}{*}{ Ulaşım sorunu } & 1 & Spor & 59 & 2,94 &, 588 & \multirow{9}{*}{1,583} & \multirow{9}{*}{, 142 } \\
\hline & 2 & Müzik & 17 & 3,07 & ,635 & & \\
\hline & 3 & Sahne & 10 & 3,02 & ,606 & & \\
\hline & 4 & $\begin{array}{l}\text { Mesleki } \\
\text { Gelişim }\end{array}$ & 8 & 2,96 & ,589 & & \\
\hline & 5 & Dikiş & 30 & 3,31 & ,468 & & \\
\hline & 6 & Öğretmen & 36 & 3,05 & 632 & & \\
\hline & 7 & El sanatları & 34 & 3,25 &, 484 & & \\
\hline & 8 & Programlama & 10 & 3,05 &, 872 & & \\
\hline & 9 & Toplam & 204 & 3,09 & ,591 & & \\
\hline
\end{tabular}




\begin{tabular}{|c|c|c|c|c|c|c|c|}
\hline \multirow{9}{*}{$\begin{array}{l}\text { Tesis } \\
\text { yetersizliği }\end{array}$} & 1 & Spor & 59 & 3,21 &, 526 & \multirow{9}{*}{, 362} & \multirow{9}{*}{,923 } \\
\hline & 2 & Müzik & 17 & 3,13 &, 625 & & \\
\hline & 3 & Sahne & 10 & 3,27 & ,570 & & \\
\hline & 4 & $\begin{array}{l}\text { Mesleki } \\
\text { Gelişim }\end{array}$ & 8 & 3,28 & ,507 & & \\
\hline & 5 & Dikiş & 30 & 3,15 & ,433 & & \\
\hline & 6 & Öğretmen & 36 & 3,09 &, 555 & & \\
\hline & 7 & El sanatları & 34 & 3,19 & 480 & & \\
\hline & 8 & Programlama & 10 & 3,05 & .586 & & \\
\hline & 9 & Toplam & 204 & 3,17 &, 519 & & \\
\hline \multirow{9}{*}{$\begin{array}{l}\text { Arkadaş } \\
\text { eksikliği }\end{array}$} & 1 & Spor & 59 & 2,55 & 679 & \multirow{9}{*}{1,854} & \multirow{9}{*}{,079 } \\
\hline & 2 & Müzik & 17 & 2,80 & ,697 & & \\
\hline & 3 & Sahne & 10 & 2,53 &, 592 & & \\
\hline & 4 & $\begin{array}{l}\text { Mesleki } \\
\text { Gelişim }\end{array}$ & 8 & 2,20 & ,711 & & \\
\hline & 5 & Dikiş & 30 & 2,71 & ,572 & & \\
\hline & 6 & Öğretmen & 36 & 2,48 &, 582 & & \\
\hline & 7 & El sanatları & 34 & 2,44 & .628 & & \\
\hline & 8 & Programlama & 10 & 2,10 & ,720 & & \\
\hline & 9 & Toplam & 204 & 2,52 & ,649 & & \\
\hline
\end{tabular}

Tablo 11'de boş zaman engellerinin her boyutunun ortalamalarına bakıldığında, zaman ve ilgi eksikliği boyutunda $(\overline{\mathrm{X}}=3,00)$ ve tesis yetersizliği boyutunda $(\overline{\mathrm{X}}=3.28)$ mesleki gelişim eğitmenlerinin ortalamalarının daha yüksek olduğu, birey psikolojisi boyutu $(\overline{\mathrm{X}}=2,98)$ ve ulaşım sorunu boyutunda $(\overline{\mathrm{X}}=3,31)$ dikiş eğitmenlerinin ortalamalarının daha yüksek olduğu, bilgi eksikliği boyutunda $(\bar{X}=3,26)$ el sanatları eğitmenlerinin ortalamalarının yüksek çıktığı, arkadaş eksikliği boyutunda $(\bar{X}=2,80)$ ise müzik eğitmenlerinin ortalamasının daha yüksek olduğu tespit edilmiştir. Boyutların genel toplam ortalamalarında ise en yüksek ortalamanın tesis yetersizliği boyutunda $(\overline{\mathrm{X}}=3,17)$ olduğu görülmektedir. Mesleki branş değişkenine göre hiçbir alt boyutta anlamlı farklılık bulunmamıştır ( $\mathrm{p}>0.05)$.

\subsection{Katılımcıların Boş Zaman Engellerinin Cinsiyet Değişkeni Açısından Farklılaşma Durumu Alt Boyutlarına İlișkin Bulgular}

Eğitmenlerin boş zaman engellerinin cinsiyet değişkenine göre farklılaşma durumuna ilişskin yapılan bağımsız t-testi sonuçları Tablo 12'de sunulmuştur.

Tablo 12. Halk eğitim merkezlerinde çalışan eğitmenlerin boş zaman engellerinin cinsiyet değişkenine ilişkin t- testi sonuçları

\begin{tabular}{|c|c|c|c|c|c|c|c|}
\hline Boyutlar & Cinsiyet & $\mathbf{N}$ & $\overline{\mathbf{X}}$ & S.S. & sd & $\mathbf{t}$ & $\mathbf{p}$ \\
\hline \multirow{2}{*}{$\begin{array}{l}\text { Zaman ve ilgi } \\
\text { eksikliği }\end{array}$} & Kadın & 147 & 2,91 & ,440 & \multirow{2}{*}{202} & \multirow{2}{*}{,908 } & \multirow{2}{*}{, 365} \\
\hline & Erkek & 57 & 2,85 &, 439 & & & \\
\hline \multirow{2}{*}{$\begin{array}{l}\text { Birey } \\
\text { psikolojisi }\end{array}$} & Kadın & 147 & 2,89 & ,602 & \multirow{2}{*}{202} & \multirow{2}{*}{2,620} & \multirow{2}{*}{,009 } \\
\hline & Erkek & 57 & 2,63 & ,680 & & & \\
\hline \multirow{2}{*}{ Bilgi eksikliği } & Kadın & 147 & 3,11 & ,666 & \multirow{2}{*}{202} & \multirow{2}{*}{2,025} & \multirow{2}{*}{,044 } \\
\hline & Erkek & 57 & 2,88 & 871 & & & \\
\hline \multirow{2}{*}{ Ulaşım sorunu } & Kadın & 147 & 3,18 &, 536 & \multirow{2}{*}{202} & \multirow{2}{*}{3,882} & \multirow{2}{*}{, 000} \\
\hline & Erkek & 57 & 2,84 & ,657 & & & \\
\hline \multirow{2}{*}{$\begin{array}{l}\text { Tesis } \\
\text { yetersizliği }\end{array}$} & Kadın & 147 & 3,21 & ,487 & \multirow{2}{*}{202} & \multirow{2}{*}{2,031} & \multirow{2}{*}{,044 } \\
\hline & Erkek & 57 & 3,05 & ,581 & & & \\
\hline \multirow{2}{*}{$\begin{array}{l}\text { Arkadaş } \\
\text { eksikliği }\end{array}$} & Kadın & 147 & 2,54 & ,647 & \multirow{2}{*}{202} & \multirow{2}{*}{, 522} & \multirow{2}{*}{,602 } \\
\hline & Erkek & 57 & 2,49 & .661 & & & \\
\hline
\end{tabular}


Tablo 12'de boş zaman engellerinin her boyutunun ortalamalarına bakıldığında, zaman ve ilgi eksikliği boyutunda kadınların ortalamasının $(\overline{\mathrm{X}}=2.91)$, erkeklerin ortalamasından $(\overline{\mathrm{X}}=2.85)$, birey psikolojisi boyutunda kadınların ortalamasının $(\overline{\mathrm{X}}=3.11)$, erkeklerin ortalamasından $(\overline{\mathrm{X}}=2.63)$, bilgi eksikliği boyutunda kadınların ortalamasının $(\overline{\mathrm{X}}=3.11)$ erkeklerin ortalamasından $(\overline{\mathrm{X}}=2.88)$, ulaşım sorunu boyutunda kadınların ortalamasının $(\overline{\mathrm{X}}=3.18)$, erkeklerin ortalamasından $(\overline{\mathrm{X}}=2.84)$, tesis yetersizliği boyutunda kadınların ortalamasının $(\overline{\mathrm{X}}=3.21)$, erkeklerin ortalamasından $(\overline{\mathrm{X}}=3.05)$, arkadaş eksikliği boyutunda kadınların ortalamasının $(\overline{\mathrm{X}}=2.54)$, erkeklerin ortalamasından $(\overline{\mathrm{X}}=2.49)$ daha yüksek olduğu görülmüştür. Araştırmada boş zaman engelleri alt boyutlarından olan birey psikolojisi, bilgi eksikliği boyutunda, ulaşım sorunu boyutunda ve tesis yetersizliği boyutlarında kadınların lehine anlamlı farklılık bulunmuştur $(\mathrm{p}<0.05)$.

\subsection{Araştırmaya Katılan Eğitmenlerin Boş Zaman Engellerinin Yaş Değişseni Açısından Farklılaşma Durumu Alt Boyutlarına İlişskin Bulgular}

Eğitmenlerin boş zaman engellerinin yaş değişkenine göre farklılaşma durumuna ilişkin yapılan tek yönlü OneWay ANOVA sonuçları değerleri Tablo 13'te sunulmuştur.

Tablo 13. Halk eğitim merkezlerinde çalışan eğitmenlerin boş zaman engellerinin yaş değişkenine ilișkin OneWay ANOVA sonuçları

\begin{tabular}{|c|c|c|c|c|c|c|c|}
\hline Boyutlar & Gruplar & Yaş & $\mathbf{N}$ & $\overline{\mathbf{X}}$ & S.S. & $\mathbf{F}$ & $\mathbf{p}$ \\
\hline \multirow{7}{*}{$\begin{array}{l}\text { Zaman ve ilgi } \\
\text { eksikliği }\end{array}$} & 1 & $20-27$ yaş & 41 & 2,80 & ,434 & \multirow{7}{*}{,589 } & \multirow{7}{*}{,709 } \\
\hline & 2 & $28-35$ yaş & 50 & 2,92 & 434 & & \\
\hline & 3 & $36-43$ yaş & 57 & 2,91 & ,483 & & \\
\hline & 4 & 44-51 yaş & 31 & 2,95 & ,306 & & \\
\hline & 5 & $52-59$ yaş & 20 & 2,89 &, 522 & & \\
\hline & 6 & 60 yaş ve üzeri & 5 & 2,77 & , 458 & & \\
\hline & & Toplam & 204 & 2,89 & ,439 & & \\
\hline \multirow{7}{*}{$\begin{array}{l}\text { Birey } \\
\text { psikolojisi }\end{array}$} & 1 & $20-27$ yas & 41 & 2,81 & ,657 & \multirow{7}{*}{,947 } & \multirow{7}{*}{,452 } \\
\hline & 2 & 28-35 yaş & 50 & 2,71 & ,594 & & \\
\hline & 3 & $36-43$ yaş & 57 & 2,92 & ,598 & & \\
\hline & 4 & 44-51 yaş & 31 & 2,74 & ,717 & & \\
\hline & 5 & $52-59$ yaş & 20 & 2,95 & ,618 & & \\
\hline & 6 & 60 yaş ve üzeri & 5 & 2,60 & ,769 & & \\
\hline & & Toplam & 204 & 2,81 & ,634 & & \\
\hline \multirow{7}{*}{ Bilgi eksikliği } & 1 & $20-27$ yaş & 41 & 2,95 & ,683 & \multirow{7}{*}{,794 } & \multirow{7}{*}{, 555} \\
\hline & 2 & $28-35$ yaş & 50 & 3,02 & ,837 & & \\
\hline & 3 & $36-43$ yaş & 57 & 3,19 & ,613 & & \\
\hline & 4 & 44-51 yaş & 31 & 3,04 & ,692 & & \\
\hline & 5 & $52-59$ yaş & 20 & 2,91 & 850 & & \\
\hline & 6 & 60 yaş ve üzeri & 5 & 2,86 & 1,120 & & \\
\hline & & Toplam & 204 & 3,04 & ,604 & & \\
\hline \multirow{7}{*}{ Ulaşım sorunu } & 1 & 20-27 yaş & 41 & 3,10 & ,630 & \multirow{7}{*}{1,160} & \multirow{7}{*}{, 330} \\
\hline & 2 & $28-35$ yaş & 50 & 3,05 & ,597 & & \\
\hline & 3 & 36-43 yaş & 57 & 3,19 & ,460 & & \\
\hline & 4 & 44-51 yaş & 31 & 3,12 & ,593 & & \\
\hline & 5 & $52-59$ yaş & 20 & 2,88 & ,693 & & \\
\hline & 6 & 60 yaş ve üzeri & 5 & 2,80 & ,591 & & \\
\hline & & Toplam & 204 & 3,09 & 604 & & \\
\hline \multirow{3}{*}{$\begin{array}{l}\text { Tesis } \\
\text { yetersizliği }\end{array}$} & 1 & $20-27$ yaş & 41 & 3,18 & ,580 & \multirow{3}{*}{1,096} & \multirow{3}{*}{,364 } \\
\hline & 2 & $28-35$ yaş & 50 & 3,19 & ,596 & & \\
\hline & 3 & $36-43$ yaş & 57 & 3,19 & ,462 & & \\
\hline
\end{tabular}




\begin{tabular}{|c|c|c|c|c|c|c|c|}
\hline & 4 & 44-51 yaş & 31 & 3,22 & ,372 & & \\
\hline & 5 & $52-59$ yaş & 20 & 3,02 & ,549 & & \\
\hline & 6 & 60 yaş ve üzeri & 5 & 2,75 & ,353 & & \\
\hline & & Toplam & 204 & 3,17 & ,519 & & \\
\hline \multirow{7}{*}{$\begin{array}{l}\text { Arkadaş } \\
\text { eksikliği }\end{array}$} & 1 & 20-27 yaş & 41 & 2,52 & ,699 & \multirow{7}{*}{,260 } & \multirow{7}{*}{,934 } \\
\hline & 2 & $28-35$ yaş & 50 & 2,52 & ,628 & & \\
\hline & 3 & 36-43 yaş & 57 & 2,52 & ,651 & & \\
\hline & 4 & 44-51 yaş & 31 & 2,63 & ,622 & & \\
\hline & 5 & $52-59$ yaş & 20 & 2,45 & 677 & & \\
\hline & 6 & 60 yaş ve üzeri & 5 & 2,40 & ,722 & & \\
\hline & & Toplam & 204 & 2,52 & 649 & & \\
\hline
\end{tabular}

Tablo 13'de boș zaman engellerinin her boyutunun ortalamalarına bakıldığında, bilgi eksikliği boyutunda $(\overline{\mathrm{X}}=3,19)$ ve ulaşım sorunu boyutunda $(\overline{\mathrm{X}}=3,19) \quad 36-43$ yaş arasındaki eğitmenlerin ortalamalarının daha yüksek olduğu, zaman ve ilgi eksikliği boyutunda $(\bar{X}=2,95)$, tesis yetersizliği boyutunda $(\overline{\mathrm{X}}=3.22)$ arkadaş eksikliği boyutunda $(\overline{\mathrm{X}}=2,63) 44-51$ yaş arasındaki eğitmenlerin ortalamalarının daha yüksek olduğu, birey psikolojisi boyutunda $(\overline{\mathrm{X}}=2,95) 52-59$ yaş arasındaki eğitmenlerin ortalamalarının daha yüksek olduğu tespit edilmiştir. . Boyutların genel toplam ortalamalarında ise en yüksek ortalamanın tesis yetersizliği boyutunda $(\bar{X}=3,17)$ olduğu görülmektedir. Yine genel ortalamalara bakıldığında en düşük ortalamanın ise arkadaş eksikliği boyutunda $(\bar{X}=2,52)$ olduğu belirlenmiştir.

\subsection{Araştırmaya Katılan Eğitmenlerin Boş Zaman Engellerinin Medeni Durum Değişkeni Açısından Farklılaşma Durumu Alt Boyutlarına İlişskin Bulgular}

Eğitmenlerin boş zaman engellerinin medeni durum değişkenine göre farklılaşma durumuna ilişkin yapılan tek yönlü OneWay ANOVA sonuçları değerleri Tablo 14'te sunulmuştur.

Tablo 14. Halk eğitim merkezlerinde çalışan eğitmenlerin boş zaman engellerinin medeni durum değişkenine ilişkin OneWay ANOVA sonuçları

\begin{tabular}{|c|c|c|c|c|c|c|c|}
\hline Boyutlar & Gruplar & Medeni Durum & $\mathbf{N}$ & $\overline{\mathbf{X}}$ & S.S. & $\mathbf{F}$ & p \\
\hline \multirow{5}{*}{$\begin{array}{l}\text { Zaman ve ilgi } \\
\text { eksikliği }\end{array}$} & 1 & Evli & 119 & 2,91 & ,451 & \multirow{5}{*}{,466 } & \multirow{5}{*}{, 707} \\
\hline & 2 & Bekar & 68 & 2,86 &, 435 & & \\
\hline & 3 & Boşanmış & 9 & 2,96 & ,333 & & \\
\hline & 4 & Diğger & 8 & 2,76 & ,444 & & \\
\hline & & Toplam & 204 & 2,89 &, 439 & & \\
\hline \multirow{5}{*}{$\begin{array}{l}\text { Birey } \\
\text { psikolojisi }\end{array}$} & 1 & Evli & 119 & 2,86 & ,617 & \multirow{5}{*}{2,466} & \multirow{5}{*}{, 063} \\
\hline & 2 & Bekar & 68 & 2,72 & ,670 & & \\
\hline & 3 & Boşanmış & 9 & 3,20 &, 576 & & \\
\hline & 4 & Diğer & 8 & 2,52 & ,382 & & \\
\hline & & Toplam & 204 & 2,81 & ,634 & & \\
\hline \multirow{5}{*}{ Bilgi eksikliği } & 1 & Evli & 119 & 3,05 & ,723 & \multirow{5}{*}{1,376} & \multirow{5}{*}{251} \\
\hline & 2 & Bekar & 68 & 2,97 & ,791 & & \\
\hline & 3 & Boşanmış & 9 & 3,48 &, 412 & & \\
\hline & 4 & Diğer & 8 & 3,16 & ,563 & & \\
\hline & & Toplam & 204 & 3,04 & ,734 & & \\
\hline \multirow{5}{*}{ Ulaşım sorunu } & 1 & Evli & 119 & 3,07 & ,591 & \multirow{5}{*}{1,655} & \multirow{5}{*}{, 178 } \\
\hline & 2 & Bekar & 68 & 3,08 & ,605 & & \\
\hline & 3 & Boşanmış & 9 & 3,50 &, 559 & & \\
\hline & 4 & Diğer & 8 & 2,93 & ,395 & & \\
\hline & & Toplam & 204 & 3,09 & ,591 & & \\
\hline
\end{tabular}




\begin{tabular}{|c|c|c|c|c|c|c|c|}
\hline \multirow{5}{*}{$\begin{array}{l}\text { Tesis } \\
\text { yetersizliği }\end{array}$} & 1 & Evli & 119 & 3,17 & ,506 & \multirow{5}{*}{1,436} & \multirow{5}{*}{,233 } \\
\hline & 2 & Bekar & 68 & 3,10 &, 532 & & \\
\hline & 3 & Boşanmış & 9 & 3,44 & ,325 & & \\
\hline & 4 & Diğer & 8 & 3,31 &, 703 & & \\
\hline & & Toplam & 204 & 3,17 & ,519 & & \\
\hline \multirow{5}{*}{$\begin{array}{l}\text { Arkadaş } \\
\text { eksikliği }\end{array}$} & 1 & Evli & 119 & 2,51 & 635 & \multirow{5}{*}{,613 } & \multirow{5}{*}{607} \\
\hline & 2 & Bekar & 68 & 2,51 & ,694 & & \\
\hline & 3 & Boşanmıș & 9 & 2,48 & ,580 & & \\
\hline & 4 & Diğer & 8 & 2,83 & ,563 & & \\
\hline & & Toplam & 204 & 2,52 & ,649 & & \\
\hline
\end{tabular}

Tablo 14'de boş zaman engellerinin medeni durum değişkeni açısından her boyutunun ortalamalarına bakıldığında zaman ve ilgi eksikliği boyutunda $(\overline{\mathrm{X}}=2,96)$, birey psikolojisi boyutunda $(\overline{\mathrm{X}}=3,20)$, bilgi eksikliği boyutunda $(\overline{\mathrm{X}}=3,48)$, ulaşım sorunu boyutunda $(\overline{\mathrm{X}}=3,50)$ ve tesis yetersizliği boyutunda $(\overline{\mathrm{X}}=3,44)$ boşanmış olan eğitmenlerin ortalamalarının daha yüksek çıktığı, arkadaş eksikliği boyutunda ise $(\bar{X}=2,83)$ diğer grubunda olan eğitmenlerin ortalamalarının daha yüksek olduğu tespit edilmiştir. Boyutların genel toplam ortalamalarında ise en yüksek ortalamanın tesis yetersizliği boyutunda $(\bar{X}=3,17)$ olduğu görülmektedir. Yine genel ortalamalara bakıldığında en düşük ortalamanın ise arkadaş eksikliği boyutunda $(\overline{\mathrm{X}}=2,52)$ olduğu belirlenmiştir. Buna göre boşanmış olan kişilerin evli, bekâr ve diğer kategorisinde yer alan kişilere göre boş zaman engellerinin daha fazla olduğu söylenebilir.

\subsection{Katılımcıların Boş Zaman Engellerinin Çocuk Sahibi Olma Değiş̧keni Açısından Farklılaşma Durumu Alt Boyutlarına İliş̧kin Bulgular}

Eğitmenlerin boş zaman engellerinin çocuk sahibi olma değişkenine göre farklılaşma durumuna ilişkin yapılan tek yönlü OneWay ANOVA sonuçları değerleri Tablo 15'te sunulmuştur.

Tablo 15. Halk eğitim merkezlerinde çalışan eğitmenlerin boş zaman engellerinin çocuk sahibi olma değişkenine ilişkin OneWay ANOVA sonuçları

\begin{tabular}{|c|c|c|c|c|c|c|c|}
\hline Boyutlar & Gruplar & Çocuk Sahibi & $\mathbf{N}$ & $\overline{\mathbf{X}}$ & S.S. & $\mathbf{F}$ & p \\
\hline \multirow{5}{*}{$\begin{array}{l}\text { Zaman ve ilgi } \\
\text { eksikliği }\end{array}$} & 1 & $\begin{array}{l}\text { Çocuk Sahibi } \\
\text { Değilim }\end{array}$ & 90 & 2,85 & ,456 & \multirow{5}{*}{1,879} & \multirow{5}{*}{, 134 } \\
\hline & 2 & 1 çocuk & 38 & 2,85 & ,448 & & \\
\hline & 3 & 2 çocuk & 68 & 2,94 & ,391 & & \\
\hline & 4 & 3 cocuk & 8 & 3,19 & .534 & & \\
\hline & & Toplam & 204 & 2,89 & 439 & & \\
\hline \multirow{5}{*}{$\begin{array}{l}\text { Birey } \\
\text { psikolojisi }\end{array}$} & 1 & $\begin{array}{l}\text { Çocuk Sahibi } \\
\text { Değilim }\end{array}$ & 90 & 2,75 & 653, & \multirow{5}{*}{1,564} & \multirow{5}{*}{, 199 } \\
\hline & 2 & 1 çocuk & 38 & 2,77 & ,643 & & \\
\hline & 3 & 2 cocuk & 68 & 2,88 & 571 & & \\
\hline & 4 & 3 cocuk & 8 & 3,18 & 808 & & \\
\hline & & Toplam & 204 & 2,81 & ,634 & & \\
\hline \multirow{5}{*}{ Bilgi eksikliği } & 1 & $\begin{array}{l}\text { Çocuk Sahibi } \\
\text { Değilim }\end{array}$ & 90 & 3,01 & ,724 & \multirow{5}{*}{1,346} & \multirow{5}{*}{,261 } \\
\hline & 2 & 1 çocuk & 38 & 2,99 & ,699 & & \\
\hline & 3 & 2 cocuk & 68 & 3,06 & .775 & & \\
\hline & 4 & 3 çocuk & 8 & 3,54 & 561 & & \\
\hline & & Toplam & 204 & 3,04 & ,734 & & \\
\hline \multirow[t]{2}{*}{ Ulaşım sorunu } & 1 & $\begin{array}{l}\text { Çocuk Sahibi } \\
\text { Değilim }\end{array}$ & 90 & 3,16 & ,605 & \multirow[t]{2}{*}{2,064} & \multirow[t]{2}{*}{, 106 } \\
\hline & 2 & 1 çocuk & 38 & 2,98 &, 632 & & \\
\hline
\end{tabular}




\begin{tabular}{|c|c|c|c|c|c|c|c|}
\hline & 3 & 2 çocuk & 68 & 3,01 & ,540 & & \\
\hline & 4 & 3 çocuk & 8 & 3,40 &, 533 & & \\
\hline & & Toplam & 204 & 3,09 & ,591 & & \\
\hline & 1 & $\begin{array}{l}\text { Çocuk Sahibi } \\
\text { Değilim }\end{array}$ & 90 & 3,17 & ,538 & & \\
\hline Tesis & 2 & 1 çocuk & 38 & 3,17 & ,590 & 1254 & 201 \\
\hline yetersizliği & 3 & 2 çocuk & 68 & 3,12 & ,451 & 1,254 & 291 \\
\hline & 4 & 3 çocuk & 8 & 3,50 & ,443 & & \\
\hline & & Toplam & 204 & 3,17 & ,519 & & \\
\hline & 1 & $\begin{array}{l}\text { Çocuk Sahibi } \\
\text { Değilim }\end{array}$ & 90 & 2,52 & ,727 & & \\
\hline Arkadaş & 2 & 1 çocuk & 38 & 2,49 &, 529 & & \\
\hline eksikliği & 3 & 2 çocuk & 68 & 2,51 &, 577 & ,630 & 年, \\
\hline & 4 & 3 çocuk & 8 & 2,83 & 854 & & \\
\hline & & Toplam & 204 & 2,52 & ,649 & & \\
\hline
\end{tabular}

Tablo 15 'te boş zaman engellerinin her boyutunun ortalamalarına bakıldığında zaman ve ilgi eksikliği boyutunda $(\bar{X}=3,19)$, birey psikolojisi boyutunda $(\bar{X}=3,18)$, bilgi eksikliği boyutunda $(\bar{X}=3,54)$, ulaşım sorunu boyutunda $(\bar{X}=3,40)$, tesis yetersizliği boyutunda $(\bar{X}=3,50)$ ve arkadaş eksikliği boyutunda $(\overline{\mathrm{X}}=2,83), 3$ çocuk sahibi olan eğitmenlerin ortalamalarının daha yüksek çıktığı görülmüştür. Buna göre 3 çocuk sahibi olan bireylerin diğer bireylere göre boş zaman engellerinin daha fazla olduğu söylenebilir.

\subsection{Katılımcıların Boş Zaman Engellerinin Gelir Değişkeni Açısından Farklılaşma Durumu Alt Boyutlarına İlişkin Bulgular}

Eğitmenlerin boş zaman engellerinin gelir değişkenine göre farklılaşma durumuna ilişkin yapılan tek yönlü OneWay ANOVA sonuçları değerleri Tablo 16'da sunulmuştur.

Tablo 16. Halk eğitim merkezlerinde çalışan eğitmenlerin boş zaman engellerinin gelir değişkenine ilişkin OneWay ANOVA sonuçları

\begin{tabular}{|c|c|c|c|c|c|c|c|}
\hline Boyutlar & Gruplar & Gelir & $\mathbf{N}$ & $\overline{\mathbf{X}}$ & S.S. & $\mathbf{F}$ & $\mathbf{p}$ \\
\hline \multirow{6}{*}{$\begin{array}{l}\text { Zaman ve ilgi } \\
\text { eksikliği }\end{array}$} & 1 & 2000 TL ve alt1 & 117 & 2,87 & 426 & \multirow{6}{*}{1,003} & \multirow{6}{*}{,407 } \\
\hline & 2 & 2001-3000TL & 47 & 2,98 & ,493 & & \\
\hline & 3 & 3001-4000TL & 16 & 2,76 & ,429 & & \\
\hline & 4 & 4001-5000TL & 14 & 2,87 & ,407 & & \\
\hline & 5 & 5001TL ve üzeri & 10 & 3,00 & ,368 & & \\
\hline & & Toplam & 204 & 2,89 &, 439 & & \\
\hline \multirow{6}{*}{$\begin{array}{l}\text { Birey } \\
\text { psikolojisi }\end{array}$} & 1 & $2000 \mathrm{TL}$ ve alt1 & 117 & 2,83 & ,602 & \multirow{6}{*}{, 553} & \multirow{6}{*}{,697 } \\
\hline & 2 & 2001-3000TL & 47 & 2,86 & 653 & & \\
\hline & 3 & $3001-4000 \mathrm{TL}$ & 16 & 2,64 & 849 & & \\
\hline & 4 & 4001-5000TL & 14 & 2,67 & ,532 & & \\
\hline & 5 & 5001TL ve üzeri & 10 & 2,85 & ,704 & & \\
\hline & & Toplam & 204 & 2,81 &, 634 & & \\
\hline \multirow{6}{*}{ Bilgi eksikliği } & 1 & 2000 TL ve alt1 & 117 & 3,05 &, 727 & \multirow{6}{*}{,367 } & \multirow{6}{*}{,832 } \\
\hline & 2 & 2001-3000TL & 47 & 3,05 &, 739 & & \\
\hline & 3 & 3001-4000TL & 16 & 2,91 & ,774 & & \\
\hline & 4 & $4001-5000 \mathrm{TL}$ & 14 & 3,21 & ,780 & & \\
\hline & 5 & 5001TL ve üzeri & 10 & 2,93 & ,766 & & \\
\hline & & Toplam & 204 & 3,04 & ,734 & & \\
\hline \multirow{3}{*}{ Ulaşım sorunu } & 1 & 2000 TL ve alt1 & 117 & 3,16 &, 556 & \multirow{3}{*}{1,305} & \multirow{3}{*}{,270 } \\
\hline & 2 & $2001-3000 \mathrm{TL}$ & 47 & 3,03 & ,598 & & \\
\hline & 3 & $3001-4000 \mathrm{TL}$ & 16 & 2,96 & ,618 & & \\
\hline
\end{tabular}




\begin{tabular}{|c|c|c|c|c|c|c|c|}
\hline & 4 & 4001-5000TL & 14 & 2,85 & 670 & & \\
\hline & 5 & 5001TL ve üzeri & 10 & 3,02 & ,767 & & \\
\hline & & Toplam & 204 & 3,09 & ,591 & & \\
\hline \multirow{6}{*}{$\begin{array}{l}\text { Tesis } \\
\text { yetersizliği }\end{array}$} & 1 & 2000 TL ve altı & 117 & 3,20 & ,489 & \multirow{6}{*}{1,655} & \multirow{6}{*}{,162 } \\
\hline & 2 & 2001-3000TL & 47 & 3,04 &, 545 & & \\
\hline & 3 & 3001-4000TL & 16 & 3,28 & ,561 & & \\
\hline & 4 & 4001-5000TL & 14 & 3,33 & ,496 & & \\
\hline & 5 & 5001TL ve üzeri & 10 & 3,00 & ,634 & & \\
\hline & & Toplam & 204 & 3,17 & ,519 & & \\
\hline \multirow{6}{*}{$\begin{array}{l}\text { Arkadaş } \\
\text { eksikliği }\end{array}$} & 1 & 2000 TL ve alt 1 & 117 & 2,48 & ,688 & \multirow{6}{*}{,987 } & \multirow{6}{*}{,416 } \\
\hline & 2 & 2001-3000TL & 47 & 2,60 & ,626 & & \\
\hline & 3 & 3001-4000TL & 16 & 2,37 & ,619 & & \\
\hline & 4 & 4001-5000TL & 14 & 2,64 &, 530 & & \\
\hline & 5 & 5001TL ve üzeri & 10 & 2,76 & ,417 & & \\
\hline & & Toplam & 204 & 2,52 & 649 & & \\
\hline
\end{tabular}

Tablo 16'da boș zaman engellerinin her boyutunun ortalamalarına bakıldı ğında zaman ve ilgi eksikliği boyutunda $(\overline{\mathrm{X}}=3,00)$ ve arkadaş eksikliği boyutunda $(\overline{\mathrm{X}}=2,76) 5001 \mathrm{TL}$ ve üzeri gelire sahip olan eğitmenlerde daha yüksek çıktığ arasındaki gelire sahip olan eğitmenlerin ortalamalarının daha yüksek olduğu, bilgi eksikliği boyutunda $(\overline{\mathrm{X}}=3,21)$ ve tesis yetersizliği boyutunda $(\overline{\mathrm{X}}=3,33)$ 4001-5000TL arasindaki gelire sahip olan eğitmenlerin ortalamalarının daha yüksek olduğu, ulaşım sorunu boyutunda $(\bar{X}=3,16)$ 2000TLve altı gelire sahip olanların ortalamalarının daha yüksek olduğu görülmüştür. Buna göre eğitmenlerin gelir düzeylerinin çok yüksek ya da çok düşük olması boş zaman engelleri boyutları arasında farklı görülse de tam olarak bir belirleyicilik görülmediği yorumu yapılabilir.

\subsection{Katılımcıların Boş Zaman Engellerinin Eğitim Düzeyi Değişseni Açısından Farklılaşma Durumu Alt Boyutlarına İlişkin Bulgular}

Eğitmenlerin boş zaman engellerinin eğitim düzeyi değişkenine göre farklılaşma durumuna ilişkin yapılan tek yönlü OneWay ANOVA sonuçları değerleri Tablo 17'de sunulmuştur.

Tablo 17. Halk eğitim merkezlerinde çalışan eğitmenlerin boş zaman engellerinin eğitim düzeyi değişkenine iliş̧in OneWay ANOVA sonuçları

\begin{tabular}{|c|c|c|c|c|c|c|c|}
\hline Boyutlar & Gruplar & Eğitim Durumu & $\mathbf{N}$ & $\overline{\mathbf{X}}$ & S.S. & $\mathbf{F}$ & $\mathbf{p}$ \\
\hline \multirow{5}{*}{$\begin{array}{l}\text { Zaman ve ilgi } \\
\text { eksikliği }\end{array}$} & 1 & Lise Mezunu & 70 & 2,98 & ,414 & \multirow{5}{*}{1,847} & \multirow{5}{*}{, 140 } \\
\hline & 2 & Lisans & 93 & 2,85 & ,421 & & \\
\hline & 3 & Lisans Üstü & 11 & 2,94 &, 429 & & \\
\hline & 4 & Diğer & 30 & 2,80 &, 530 & & \\
\hline & & Toplam & 204 & 2,89 & ,439 & & \\
\hline \multirow{5}{*}{$\begin{array}{l}\text { Birey } \\
\text { psikolojisi }\end{array}$} & 1 & Lise Mezunu & 70 & 2,85 & ,631 & \multirow{5}{*}{,420 } & \multirow{5}{*}{, 739} \\
\hline & 2 & Lisans & 93 & 2,78 & ,649 & & \\
\hline & 3 & Lisans üstü & 11 & 2,96 & ,487 & & \\
\hline & 4 & Diğer & 30 & 2,78 & ,653 & & \\
\hline & & Toplam & 204 & 2,81 & ,634 & & \\
\hline \multirow{5}{*}{ Bilgi eksikliği } & 1 & Lise Mezunu & 70 & 3,19 &, 675 & \multirow{5}{*}{1,489} & \multirow{5}{*}{,219 } \\
\hline & 2 & Lisans & 93 & 2,98 & ,754 & & \\
\hline & 3 & Lisans Üstü & 11 & 2,87 & ,637 & & \\
\hline & 4 & Diğer & 30 & 2,96 & ,813 & & \\
\hline & & Toplam & 204 & 3,04 & ,734 & & \\
\hline \multirow{2}{*}{ Ulaşım sorunu } & 1 & Lise Mezunu & 70 & 3,15 &, 532 & \multirow{2}{*}{,667 } & \multirow{2}{*}{,573 } \\
\hline & 2 & Lisans & 93 & 3,04 & 603 & & \\
\hline
\end{tabular}




\begin{tabular}{|c|c|c|c|c|c|c|c|}
\hline & 3 & Lisans Üstü & 11 & 3,22 &, 719 & & \\
\hline & 4 & Diğer & 30 & 3,06 & ,646 & & \\
\hline & & Toplam & 204 & 3,09 & ,591 & & \\
\hline \multirow{5}{*}{$\begin{array}{l}\text { Tesis } \\
\text { yetersizliği }\end{array}$} & 1 & Lise Mezunu & 70 & 3,18 &, 423 & \multirow{5}{*}{,744 } & \multirow{5}{*}{,527 } \\
\hline & 2 & Lisans & 93 & 3,19 &, 576 & & \\
\hline & 3 & Lisans Üstü & 11 & 3,22 & ,493 & & \\
\hline & 4 & Diğer & 30 & 3,04 &, 549 & & \\
\hline & & Toplam & 204 & 3,17 & .519 & & \\
\hline \multirow{5}{*}{$\begin{array}{l}\text { Arkadaş } \\
\text { eksikliği }\end{array}$} & 1 & Lise Mezunu & 70 & 2,53 &, 588 & \multirow{5}{*}{,024 } & \multirow{5}{*}{,995 } \\
\hline & 2 & Lisans & 93 & 2,52 &, 650 & & \\
\hline & 3 & Lisans Üstü & 11 & 2,48 & 821 & & \\
\hline & 4 & Diğer & 30 & 2,54 &, 745 & & \\
\hline & & Toplam & 204 & 2,52 & ,649 & & \\
\hline
\end{tabular}

Tablo 17'de boş zaman engellerinin her boyutunun ortalamalarına bakıldığında zaman ve ilgi eksikliği boyutunda $(\overline{\mathrm{X}}=2,98)$ ve bilgi eksikliği boyutunda $(\overline{\mathrm{X}}=3,19)$ lise mezunu olan eğitmenlerin ortalamalarının yüksek olduğu, birey psikolojisi boyutunda $(\bar{X}=2,96)$, ulaşım sorunu boyutunda $(\bar{X}=3,22)$ ve tesis yetersizliği boyutunda $(\bar{X}=3,22)$ lisansüstü eğitim durumunda olan eğitmenlerin ortalamalarının daha yüksek olduğu, arkadaş eksikliği boyutunda ise $(\overline{\mathrm{X}}=2,54)$ diğer grubunda yer alan eğitmenlerin ortalamalarının daha yüksek olduğu görülmüştür. Bu sonuçlardan hareketle özellikle de lisansüstü eğitim yapan kişilerin boş zaman engeli boyutları açısından biraz daha fazla engelle karşılaştıkları söylenebilir.

\subsection{Katılımcıların Boş Zaman Engellerinin Çalışma Yılı Değişkeni Açısından Farklılaşma Durumu Alt Boyutlarına İliş̧kin Bulgular}

Eğitmenlerin boş zaman engellerinin çalışma yılı değişkenine göre farklılaşma durumuna ilişkin yapılan tek yönlü OneWay ANOVA sonuçları değerleri Tablo 18' de sunulmuştur.

Tablo 18. Halk eğitim merkezlerinde çalışan eğitmenlerin boş zaman engellerinin çalışma yılı değişkenine ilişkin OneWay ANOVA sonuçları

\begin{tabular}{|c|c|c|c|c|c|c|c|}
\hline Boyutlar & Gruplar & Çalışma Yılı & $\mathbf{N}$ & $\overline{\mathbf{X}}$ & S.S. & $\mathbf{F}$ & p \\
\hline \multirow{5}{*}{$\begin{array}{l}\text { Zaman ve ilgi } \\
\text { eksikliği }\end{array}$} & 1 & $1-3$ y1l & 72 & 2,82 &, 452 & \multirow{5}{*}{2,023} & \multirow{5}{*}{,112 } \\
\hline & 2 & $4-6$ y1l & 44 & 2,87 & ,397 & & \\
\hline & 3 & 7-9 y1l & 20 & 2,86 & ,484 & & \\
\hline & 4 & 10 yil ve üzeri & 68 & 3,00 &, 429 & & \\
\hline & & Toplam & 204 & 2,89 & ,439 & & \\
\hline \multirow{5}{*}{$\begin{array}{l}\text { Birey } \\
\text { psikolojisi }\end{array}$} & 1 & $1-3$ y1l & 72 & 2,85 & ,608 & \multirow{5}{*}{1,679} & \multirow{5}{*}{,173 } \\
\hline & 2 & $4-6$ y1l & 44 & 2,68 & ,651 & & \\
\hline & 3 & $7-9$ y1l & 20 & 2,65 &, 593 & & \\
\hline & 4 & 10 y1l ve üzeri & 68 & 2,91 &, 650 & & \\
\hline & & Toplam & 204 & 2,81 & ,634 & & \\
\hline \multirow{5}{*}{ Bilgi eksikliği } & 1 & $1-3$ y1l & 72 & 2,94 & ,780 & \multirow{5}{*}{,982 } & \multirow{5}{*}{,402 } \\
\hline & 2 & $4-6$ y1l & 44 & 3,03 &, 835 & & \\
\hline & 3 & $7-9$ y1l & 20 & 3,05 & ,575 & & \\
\hline & 4 & 10 yıl ve üzeri & 68 & 3,16 &, 650 & & \\
\hline & & Toplam & 204 & 3,04 &, 734 & & \\
\hline \multirow{6}{*}{ Ulaşım sorunu } & 1 & $1-3$ y1l & 72 & 3,09 & ,605 & \multirow{5}{*}{,287 } & \multirow{5}{*}{, 835} \\
\hline & 2 & $4-6$ y1l & 44 & 3,03 & ,588 & & \\
\hline & 3 & $7-9$ y1l & 20 & 3,18 &, 584 & & \\
\hline & 4 & 10 yıl ve üzeri & 68 & 3,09 & ,590 & & \\
\hline & & Toplam & 204 & 3,09 & ,591 & & \\
\hline & 1 & $1-3 \mathrm{y} 11$ & 72 & 3,16 & ,545 & 1,192 & ,314 \\
\hline
\end{tabular}




\begin{tabular}{|c|c|c|c|c|c|c|c|}
\hline \multirow{4}{*}{$\begin{array}{l}\text { Tesis } \\
\text { yetersizliği }\end{array}$} & 2 & $4-6$ y1l & 44 & 3,14 & ,563 & & \\
\hline & 3 & $7-9$ y1l & 20 & 3,00 &, 421 & & \\
\hline & 4 & 10 yıl ve üzeri & 68 & 3,24 & , 482 & & \\
\hline & & Toplam & 204 & 3,17 & ,519 & & \\
\hline \multirow{5}{*}{$\begin{array}{l}\text { Arkadaş } \\
\text { eksikliği }\end{array}$} & 1 & $1-3$ y1l & 72 & 2,56 & 655 & \multirow{5}{*}{2,345} & \multirow{5}{*}{,074 } \\
\hline & 2 & $4-6$ y1l & 44 & 2,31 &, 570 & & \\
\hline & 3 & $7-9$ y1l & 20 & 2,48 & ,679 & & \\
\hline & 4 & 10 yıl ve üzeri & 68 & 2,63 & ,663 & & \\
\hline & & Toplam & 204 & 2,52 & ,649 & & \\
\hline
\end{tabular}

Tablo 18'de boş zaman engellerinin her boyutunun ortalamalarına bakıldığında zaman ve ilgi eksikliği boyutunda $(\overline{\mathrm{X}}=3,00)$, birey psikolojisi boyutunda $(\overline{\mathrm{X}}=2,91)$, bilgi eksikliği boyutunda $(\bar{X}=3,16)$, tesis yetersizliği boyutunda $(\bar{X}=3,24)$ ve arkadaş eksikliği boyutunda $(\bar{X}=2,63) 10$ yıl ve üzeri yıl çalışan eğitmenlerin ortalamalarının daha yüksek olduğu, ulaşım sorunu boyutu $(\bar{X}=3,18)$ 7-9 yıl arasında çalışan eğitmenlerin ortalamalarının daha yüksek olduğu tespit edilmiştir. Buna göre 10 yıl ve üzerinde çalışan bireylerin boş zaman engellerine daha çok maruz kaldıkları söylenebilir.

\subsection{Katılımcıların Boş Zaman Engellerinin Boş Saat Değişkeni Açısından Farklılaşma Durumu Alt Boyutlarına İlişkin Bulgular}

Eğitmenlerin boş zaman engellerinin boş saat değişkenine göre farklılaşma durumuna ilişkin yapılan tek yönlü OneWay ANOVA sonuçları değerleri Tablo 18' da sunulmuştur.

Tablo 19. Halk eğitim merkezlerinde çalışan eğitmenlerin boş zaman engellerinin boş saat değişkenine ilişkin OneWay ANOVA sonuçları

\begin{tabular}{|c|c|c|c|c|c|c|c|c|}
\hline Boyutlar & Gruplar & Boş Saat & $\mathbf{N}$ & $\overline{\mathbf{X}}$ & S.S & $\mathbf{F}$ & $\mathbf{p}$ & $\begin{array}{c}\text { Anlamlı } \\
\text { Fark }\end{array}$ \\
\hline \multirow{5}{*}{$\begin{array}{l}\text { Zaman ve } \\
\text { ilgi eksikliği }\end{array}$} & 1 & 1-3 saat & 130 & 2,96 &, 445 & \multirow{5}{*}{3,014} & \multirow{5}{*}{,031 } & \multirow{5}{*}{$1-3$} \\
\hline & 2 & 4-6 saat & 58 & 2,78 &, 381 & & & \\
\hline & 3 & 7-9 saat & 11 & 2,71 & 592 & & & \\
\hline & 4 & $\begin{array}{c}9 \text { saat ve } \\
\text { üzeri }\end{array}$ & 5 & 2,80 & ,216 & & & \\
\hline & & Toplam & 204 & 2,89 & ,439 & & & \\
\hline \multirow{5}{*}{$\begin{array}{l}\text { Birey } \\
\text { psikolojisi }\end{array}$} & 1 & 1-3 saat & 130 & 2,91 & ,644 & \multirow{5}{*}{2,987} & \multirow{5}{*}{, $032 *$} & \multirow{5}{*}{$1-2$} \\
\hline & 2 & 4-6 saat & 58 & 2,63 &, 549 & & & \\
\hline & 3 & $7-9$ saat & 11 & 2,71 & ,760 & & & \\
\hline & 4 & $\begin{array}{c}9 \text { saat ve } \\
\text { üzeri }\end{array}$ & 5 & 2,63 & ,616 & & & \\
\hline & & Toplam & 204 & 2,81 & ,634 & & & \\
\hline \multirow{5}{*}{$\begin{array}{l}\text { Bilgi } \\
\text { eksikliğgi }\end{array}$} & 1 & 1-3 saat & 130 & 3,14 & ,696 & \multirow{5}{*}{2,089} & \multirow{5}{*}{, 103} & \multirow{5}{*}{ - } \\
\hline & 2 & 4-6 saat & 58 & 2,87 & ,771 & & & \\
\hline & 3 & 7-9 saat & 11 & 2,96 & 887 & & & \\
\hline & 4 & $\begin{array}{c}9 \text { saat ve } \\
\text { üzeri }\end{array}$ & 5 & 2,80 & 649 & & & \\
\hline & & Toplam & 204 & 3,04 & ,734 & & & \\
\hline \multirow{6}{*}{$\begin{array}{l}\text { Ulaşım } \\
\text { sorunu }\end{array}$} & 1 & 1-3 saat & 130 & 3,20 &, 562 & \multirow{5}{*}{4,511} & \multirow{5}{*}{, $004 *$} & \multirow{5}{*}{$1-2$} \\
\hline & 2 & 4-6 saat & 58 & 2,88 & ,607 & & & \\
\hline & 3 & 7-9 saat & 11 & 3,00 & ,651 & & & \\
\hline & 4 & $\begin{array}{c}9 \text { saat ve } \\
\text { üzeri }\end{array}$ & 5 & 2,80 & ,370 & & & \\
\hline & & Toplam & 204 & 3,09 & ,591 & & & \\
\hline & 1 & 1-3 saat & 130 & 3,24 &, 503 & 3,420 &, 018 & \\
\hline
\end{tabular}




\begin{tabular}{|c|c|c|c|c|c|c|c|c|}
\hline \multirow{4}{*}{$\begin{array}{l}\text { Tesis } \\
\text { yetersizliği }\end{array}$} & 2 & 4-6 saat & 58 & 3,06 &, 505 & & & \multirow{4}{*}{-} \\
\hline & 3 & $7-9$ saat & 11 & 3,04 &, 545 & & & \\
\hline & 4 & $\begin{array}{c}9 \text { saat ve } \\
\text { üzeri }\end{array}$ & 5 & 2,70 & ,670 & & & \\
\hline & & Toplam & 204 & 3,17 & ,519 & & & \\
\hline \multirow{5}{*}{$\begin{array}{l}\text { Arkadaş } \\
\text { eksikliği }\end{array}$} & 1 & $1-3$ saat & 130 & 2,56 & ,659 & \multirow{5}{*}{, 560} & \multirow{5}{*}{,642 } & \multirow{5}{*}{-} \\
\hline & 2 & 4-6 saat & 58 & 2,45 & ,642 & & & \\
\hline & 3 & $7-9$ saat & 11 & 2,39 & ,680 & & & \\
\hline & 4 & $\begin{array}{c}9 \text { saat ve } \\
\text { üzeri }\end{array}$ & 5 & 2,60 & ,434 & & & \\
\hline & & Toplam & 204 & 2,52 & 649 & & & \\
\hline
\end{tabular}

Tablo 19' da boş zaman engellerinin her boyutunun ortalamalarına bakıldığında zaman ve ilgi eksikliği boyutunda $(\bar{X}=2,96)$, birey psikolojisi boyutunda $(\bar{X}=2,91)$, bilgi eksikliği boyutunda $(\bar{X}=3,14)$, ulaşım sorunu boyutunda $(\bar{X}=3,20)$ ve tesis yetersizliği boyutunda $(\bar{X}=3,24) 1-3$ saat arasında boş vakitleri olan eğitmenlerin ortalamalarının daha yüksek çıktığı, arkadaş eksikliği boyutunda $(\bar{X}=2,6) 9$ saat ve üzeri boş vakitleri olan eğitmenlerin ortalamalarının daha yüksek çıktığı görülmüştür. Bu bulguya göre boş vakitleri az olan kişilerin daha çok boş zaman engeli yaşadıkları yorumu yapılabilir.

Araştırmada boş zaman engelleri ölçeği zaman ve ilgi eksikliği $(F=3,014 ; p<0.05)$ ve birey psikolojisi boyutunda $(\mathrm{F}=2,987 ; \mathrm{p}<0.05)$ alt boyutlarında $1-3$ saat aralı̆̆ında boş saati olanlar lehine anlamlı farklılık tespit edilmiştir. Boş zaman engelleri ölçeği alt boyutlarından olan ulaşım sorunu boyutunda 1-3 saat aralığında boş vakitleri olan kişilerle 4-6 saat aralığında boş vakitleri olan kişiler arasında 1-3 saat aralığı boş olanlar lehine anlamlı farklılık tespit edilmiştir $(\mathrm{F}=4,511 ; \mathrm{p}<0.05)$. Ayrıca boş zaman engelleri alt boyutlarından tesis yetersizliği boyutunda 1 3 saat aralığ boş vakitleri olan kişiler 9 saat ve üzeri aralığında boş vakitleri olan kişiler arasında 1-3 saat aralığında olanlar lehine anlamlı farklılık tespit edilmiştir. $(F=3,420 ; p<0.05)$.

\section{Tartışma}

Halk eğitim merkezlerinde çalışmakta olan bireylerin rekreatif engellerini (boş zaman engelleri) tespit etmek amacıyla yürütülen bu çalışmada elde edilen sonuçlar sırası ile sunulmuştur.

Halk eğitim merkezinde çalışmakta olan eğitmenlerin boş zaman engelleri ölçeğinin alt boyutları incelendiğinde ortalamalarının orta düzeye yakın, ancak yüksek olduğu ve boş zaman engellerine maruz kalındığı sonucuna varılmıştır. Ölçekten elde edilen puan ortalamalarının en yüksek ortalaması tesis yetersizliği boyutunda $(\overline{\mathrm{X}}=3,17)$ görülürken en düşük ortalama arkadaş eksikliği boyutunda $(\overline{\mathrm{X}}=2,52)$ görülmüştür.

Araştırmadan elde edilen bu bulgu, çeşitli örneklem grupları üzerinde konu ile ilgili yapılan çalışmalardan elde edilen bulgularla büyük ölçüde benzerlik göstermektedir. Has'ın (2016) yapmış olduğu sağlik sektöründe çalışanların boş zamanlarında rekreasyon etkinliklerine katılımlarının önündeki engellerin belirlenmesine yönelik çalışmada rekreatif etkinliklere katılımın önündeki engellerin genellikle tesis yetersizliği ile ilgili olduğu ve arkadaş eksikliği alt boyutunun çok fazla engel oluşturmadığı sonucuna ulaşılmıştır. Emir (2012)'in çalışmasında da benzer biçimde rekreatif etkinliklere katılımın önündeki engellerin genellikle tesis ve zaman yetersizliği ile ilgili olduğu sonucuna varılmıştır.

Adayların boş zaman engellerinin mesleki branş, yaş, medeni durum, çocuk sayısı, aylık geliri, eğitim düzeyi, meslekte çalışma yılı açısından anlamlı bir farklılık göstermediği, boş zaman engellerinin bazı alt boyutlarının cinsiyet ve boş zaman değişkenine göre anlamlı farklılık gösterdiği tespit edilmiştir. 
Araştırmada mesleki branş değişkenine göre mesleki gelişim eğitmenleri, dikiş eğitmenleri, el sanatları eğitmenleri ve müzik eğitmenlerinin ortalamalarının diğer branşlara göre daha yüksek çıktığı sonucuna varılmış ve bu bulgudan hareketle eğitmenlerin daha çok boş zaman engeli ile karşılaştıkları söylenebilir.

Araştırma bulguları cinsiyet değişkeni açısından incelendiğinde boş zaman engellerinin tüm alt boyutlarında kadınların erkeklere oranla ortalamalarının daha yüksek olduğu görülmüş, buna göre kadınların boş zaman engellerinin erkeklerden daha fazla olabileceği sonucuna ulaşılmıştır. Buna ek olarak birey psikolojisi boyutunda, bilgi eksikliği boyutunda, ulaşım sorunu boyutunda ve tesis yetersizliği boyutlarında kadınların lehine anlamlı farklılık olduğu görülmüştür. Sabanc1 (2016) yapmış olduğu çalışmasında cinsiyet değişkenine göre akademisyenlerin, boş zaman engelleri ölçeği, zaman ve ilgi eksikliği, birey psikolojisi, bilgi eksikliği, ulaşım sorunu alt boyutlarına ait puan ortalamalarının kadın akademisyenler lehine, arkadaş eksikliği alt boyutuna ait puan ortalamalarının ise erkek akademisyenler lehine anlamlı düzeyde farklılaştığını göstermiştir. Özşaker (2012) tarafından yapılan bir araştırmada ise üniversite ögrencilerinin boş zaman aktivitelerine katılamama nedenleri incelenmiş ve boş zamanlara katılımı engelleyen faktörler arasındaki alt boyutlar ile cinsiyet arasında anlamlı bir ilişki olduğu görülmüştür.

Araştırma yaş değişkeni açısından incelendiğinde boş zaman engelleri ölçeğinin alt boyutlarından olan tesis yetersizliği özellikle de 44-51 yaş arası bireyler açısından en yüksek ortalamaya sahiptir. Buna göre yaş değişkeninin tüm boyutlar açısından anlamlı bir farklılık göstermediği görülse de genel olarak ortalamanın üzerinde olduğu söylenebilir. Has (2016)'ın çalışmasına göre yaş değişkeni açısından tesis ve arkadaş eksikliği alt boyutlarında anlamlı fark görülmüss ancak, bireysel psikolojisi, bilgi eksikliği, zaman ve ilgi eksikliği alt boyutlarında anlamlı fark görülmemiştir. Yapılan bazı çalışma sonuçlarında da yaş değişkeninin boş zaman engellerinin bazı alt boyutlara göre anlamlı farklılık gösterdiği tespit edilmiştir (Emir, 2012; Polat, 2017; Sabanc1, 2016).

Araştırmada medeni durum değişkeninin anlamlı bir fark göstermediği görülse de birçok alt boyutta boşanmış kişilerin, evli, bekâr ve diğer kategorisinde yer alan kişilere oranla ortalamasının daha yüksek çıktığı görülmüştür. Bekâr olanların ortalamalarının ise diğer gruplar arasında en düşük olduğu tespit edilmiştir. Yapmış olduğumuz çalışmayı destekler nitelikte olan Öztürk'ün (2013) yapmış olduğu sanayi çalışanların medeni durumlarına bakıldığında bekâr olanlar evli olanlara göre daha fazla rekreatif etkinliklere katıldıkları sonucuna varılmıştır. Dalay'ın (2018) öğretim elemanlarının rekreatif faaliyetlerine katılımlarının engellenmesine ilişkin alt boyutların düzenli fiziksel aktiviteye katılım durumları ve katılımcıların medeni duruma göre karşılaştırılmasında, tüm alt boyutların toplam puanlar bakımından bu iki değişkene göre istatistiksel olarak anlamlı bir farklılık olmadığı tespit edilmiştir. Çalı̧̧mamızın bulgularının aksine Sabancı (2016) çalışmasında boş zaman engelleri ölçeğinin bazı alt boyutlarının bekar akademisyenler lehine anlamlı düzeyde farklılık gösterdiği sonucuna ulaşmıştır.

Çocuk sayısı değişkeni açısından yapmış olduğumuz araştırma sonuçları 3 çocuk sahibi olan kişilerin daha fazla boş zaman engeli yaşadığını gösterse de gruplar arasında bir anlamlı farklılık bulunmamıştır. Çocuk sahibi olmayan bireylerin ise birçok boyutta rekreatif bir engel yaşamadıkları tespit edilmiştir. $\mathrm{Bu}$ istatistikler doğrultusunda çocuk sayısı arttıkça kişinin rekreatif etkinliklere katılma engelinin de artı̧̧ gösterebileceği söylenebilir.

Araştırma bulguları incelendiğinde aylık toplam gelir düzeyinin anlamlı bir fark göstermediği ancak zaman ve ilgi eksikliği boyutunda ve arkadaş eksikliği boyutunda 5001TL ve üzeri gelire sahip olan eğitmenlerde daha yüksek çıktığı, birey psikolojisi boyutunda 20013000TLarasındaki gelire sahip olan eğitmenlerin ortalamalarının daha yüksek olduğu, bilgi eksikliği boyutunda ve tesis yetersizliği boyutunda 4001-5000TL arasındaki gelire sahip olan eğitmenlerin ortalamalarının daha yüksek olduğu, ulaşım sorunu boyutunda 2000TLve altı gelire sahip olanların ortalamalarının daha yüksek olduğu görülmüştür. Çalışmamızı destekler nitelikte 
olan Dalay' in (2018) çalışması öğretim elemanlarının rekreasyonel faaliyetlerine katılımlarının engellenmesine ilişkin alt boyutların aylık gelir durumuna göre karşılaştırılmasında, toplam puanlar bakımından aylık gelir durumları arasında istatistiksel olarak anlamlı bir farklılık olmadığ 1 tespit edilmiştir. Dong ve Chick (2012) altı şehirde karşılaştırmalı olarak yaptıkları çalışmada para faktörünün boş zaman engelleri kapsamında en fazla dikkat çekilen faktör olduğunu belirtmişlerdir.

Mevcut araştırmada bir diğer değişken olan eğitim düzeyi değişkenine göre boş zaman engeli ortalamalarının en yükseği lisansüstü eğitim durumunda olan kişilerde görülmüştür. Eğitim seviyesi arttıkça kişilerdeki boş zaman engelinin arttığı bunun sebebi olarak da eğitim yoğunluğunun fazla olması gösterilebilir. Buna rağmen gruplar arasında anlamlı bir farklılık bulunmamıştır. Has (2016) ve Öztürk (2013) yapmış olduğu çalışmasında, bizim çalışmamızın aksine bazı alt boyutlar arasında anlamlı fark tespit emiş ve eğitim seviyeleri arttıkça boş zaman engellerin azaldığı sonucuna ulaşmıştır.

Meslekte çalışma yılı bakımından araştırma sonuçlarında anlamlı bir fark görülmemiştir. Ancak 10 yıl ve üzerinde çalışan bireylerin diğer gruptaki bireylere nazaran daha az rekreatif etkinlikte bulunduğu tespit edilmiştir. Has (2016) çalışmasında zaman, alt boyutunda anlamlı fark tespit etmiş ancak diğer boyutlarda anlamlı bir fark olmadığını söylemiştir.

Günlük boş denebilecek zaman değişkeni açısından araştırmada ulaşılan sonuçlar zaman ve ilgi eksikliği, birey psikolojisi, ulaşım sorunu, tesis yetersizliği alt boyutlarında 1-3 saat arasında boşluk olan bireylerin lehine anlamlı farklılık göstermiş̧ir. Buna göre 1-3 saat aralığında boş zamana sahip olan bireylerin rekreatif etkinliklere katılma konusunda sıkıntı yaşadıkları söylenebilir.

\section{Sonuç ve Öneriler}

Araştırmada katılımcıların rekreatif etkinliklere katılımını etkileyen faktörlerde ölçeğin alt boyutları incelendiğinde ortalamalarının orta düzeye yakın, ancak yüksek olduğu ve boş zaman engellerine maruz kalındığı görülmektedir. Ölçekten elde edilen puan ortalamalarının en yüksek ortalaması tesis yetersizliği boyutunda görülürken en düşük ortalama arkadaş eksikliği boyutunda görülmüştür.

Çalışmanın sonuçları göz önüne alındığında halk eğitim merkezlerinde çalışmakta olan eğitmenlerin son zamanlarda gittikçe artması sebebiyle benzer çalışmalar yapılabilir, daha fazla örneklem grubuna dahil edilebilir. Yine aynı çalışma farklı illerdeki halk eğitim merkezlerinde uygulanarak geniş çaplı çalışma yürütülebilir ve eğitmenlerin illere göre durumları tespit edilebilir buna göre tespit edilen noktalar geliştirilebilir. Eğitmenlerin boş zaman engellerini en aza indirmek ve sportif rekreatif etkinliklere katılmaları için çeşitli teşvik edici bilgilendirmeler ve yönlendirmeler yapılabilir. Kurum içi belirli zamanlarda aktiviteler ve spor turnuvaları düzenlenerek geleneksel hale getirilebilir.

\section{Kaynakça}

Alghenaim, K. F. (2013). Recreating urban space in Saudiarabia: private sector participation in leisure, sportsandrecreation (Published doctoral dissertation). Middle Tennessee State University.

Arslan, S (2013). Serbest zaman- rekreasyon ve serbest zaman eğitimi. Ankara: Nobel Akademik Yayıncilik.

Ayhan, C. (2017). Aktif sporcuların rekreatif etkinliklere katılımlarına engel oluşturabilecek faktörlerin yaşam tatmini ve yaşam kalitesi üzerine etkisi (Yayımlanmamış yüksek lisans tezi). Sakarya Üniversitesi, Sakarya. 
Aytaç Ö. (1994, Kasım). Modern toplumda boş zaman olgusu. Dünya'da ve Türkiye'de sosyolojik gelişmeler. I. Ulusal Sosyoloji Kongresi'nde sunulan bildiri (3-5 Kasım 1993 İzmir), Sosyoloji Derneği Yayınları, (1):341-356.

Caldwell, L. L. (2005). Leisureandhealth: why is leisuretherapeutic?. British Journal of Guidance \& Counselling, 33(1), 7-26.

Crawford D. ve Godbey, G. (1987). Reconceptualizing barriers to family leisure. Leisure Sciences 9, 119-127.

Dalay, Y. (2018). Akademik personelin rekreasyonel faaliyetlere katılımlarını engelleyen faktörlerin belirlenmesi (Batman Üniversitesi örneği) (Yayımlanmamış yüksek lisans tezi). Batman Üniversitesi, Batman.

Dong E. ve Chick G. (2012). Leisureconstraints in Sixchinesecities. Leisure Science, 34, 417435.

Ekinci, E., Kalkavan, A., Üstün, D. ve Gürbüz, B. (2014). Üniversite öğrencilerinin sportif ve sportif olmayan rekreatif etkinliklere katılımlarına engel olabilecek unsurların incelenmesi. Spor ve Eğitim Bilimleri Dergisi, 1(1), 1-13.

Emir, E. (2012). Rekreatif etkinliklere katılımın önündeki engellerin belirlenmesi: üniversite ögrencileri örneği (Yayımlanmamış yüksek lisans tezi). Karadeniz Teknik Üniversitesi, Trabzon.

Ergül, O.K. (2008). Üniversite gençliğinin sportif rekreasyon etkinliklerine yönelik ilgileri ve katılma düzeylerinin belirlenmesi (Yayımlanmamış yüksek lisans tezi). Celal Bayar Üniversitesi, Manisa.

Güngörmüş, H.A. (2007). Özel sağllk spor merkezlerinden hizmet alan bireyleri rekreasyonel egzersize güdüleyen faktörler (Yayımlanmamış doktora tezi). Gazi Üniversitesi, Ankara.

Has, F. (2016). Sağllk sektöründe çalışanların boş zamanlarında rekreasyon etkinliklerine katılımlarının önündeki engellerin belirlenmesi (Osmaniye ili örneği) (Yayımlanmamış yüksek lisans tezi). Gaziantep Üniversitesi, Gaziantep.

Horner, S. ve Swarbrooke, J. (2005). Leisuremarketing: A Global Perspective (Paperback). 1st Edition. Oxford: ElsevierButterworth-Heinemann

Karaküçük, S. (1999). Rekreasyon, boş zamanları değerlendirme, kavram kapsam ve bir araştırma. Ankara: Seren Matbaacılık Yayınları.

Karaküçük, S. (2005). Rekreasyon: boş zamanları değerlendirme. Ankara: Gazi Kitabevi

Karaküçük, S. ve Gürbüz, B. (2006, Kasım). The reliability and validity of the Turkish version of" leisure constraints questionnaire(In Proceedings). 9th International Sport Sciences Congress, Muğla, Turkey.

Karaküçük, S. ve Gürbüz, B. (2007). Rekreasyon ve kent(li)leşme. Ankara: Gazi Kitabevi.

Karasar, N. (2011). Bilimsel araştırma yöntemi. Ankara: Nobel Kitabevi.

Özşaker, M. (2012). Gençlerin serbest zaman aktivitelerine katılamama nedenleri üzerine bir inceleme. Selçuk Üniversitesi Beden Eğitimi ve Spor Bilim Dergisi, 14(1), 126- 131.

Öztürk, H. (2013). Sanayi çalışanlarının rekreatif aktivitelere katılımlarının örgütsel bağlılık ve tükenmişlik düzeylerine etkisi (Gaziantep uygulaması) (Yayımlanmamış doktora tezi). Gazi Üniversitesi, Ankara.

Polat, C. (2017). Üniversite ögrencilerinin rekreasyonel etkinliklere katılım engellerinin bazı değişsenlere göre incelenmesi (Kütahya ili örneği) (Yayımlanmamış yüksek lisans tezi). Dumlupınar Üniversitesi, Kütahya. 
Sabancı, G. (2016). Öğretim elemanlarının rekreasyonel faaliyetlere katılımların engelleyen faktörlerin belirlenmesi (Yayımlanmamış yüksek lisans tezi). Selçuk Üniversitesi, Konya.

Sekot, A. (2013). Physicalactivities as a part of leisure in Czechsociety. Journal of Human Sportand Exercise, 8(2), 261-270.

Sezik Tanyeri, Ö. (2018). Bireylerin rekreatif etkinliklere bilinçli katılımlarının farklı parametrelerle incelenmesi (Yayımlanmamış yüksek lisans tezi). Atatürk Üniversitesi, Erzurum.

Şahin, İ. ve Kocabulut, Ö. (2014). Sportif rekreasyon aktivitelerine düzenli katılımı engelleyen faktörlerin incelenmesi: Akdeniz Üniversitesi Turizm Fakültesi öğrencileri üzerine bir araştırma, Journal of Recreationand TourismResearch, 1(2), 46-67.

Tel, M. ve Köksalan, B. (2008). Öğretim üyelerinin spor etkinliklerinin sosyolojik olarak incelenmesi (Doğu Anadolu örneği), Firat Üniversitesi Sosyal Bilimler Dergisi, 18(1), 261278.

Tutar, H. (2007). Zaman yönetim. Ankara: Seçkin Yayıncıl1k.

Tütüncü, Ö. ve Aydın, İ. (2014). Toplum ve açık hava rekreasyon faaliyetleri: ABD örneği. Anatolia: Turizm Araştırmaları Dergisi, 25(1), 118-120.

\section{ETIKK ve BİLIMMSEL İLKELER SORUMLULUK BEYANI}

$\mathrm{Bu}$ çalışmanın tüm hazırlanma süreçlerinde etik kurallara ve bilimsel atıf gösterme ilkelerine riayet edildiğini yazar(lar) beyan eder. Aksi bir durumun tespiti halinde Afyon Kocatepe Üniversitesi Sosyal Bilimler Dergisi'nin hiçbir sorumluluğu olmayıp, tüm sorumluluk makale yazarlarına aittir. 